\title{
Geology of Part of
}

the Townsend Valley

\section{Broadwater and Jefferson} Counties, Montana

GEOLOGICAL SURVEY BULLETIN 1042 -N

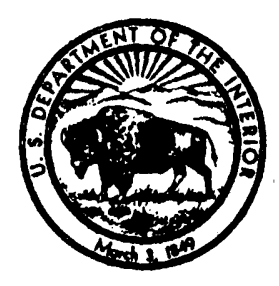





\title{
CONTRIBUTIONS TO ECONOMIC GEOLOGY
}

\section{GEOLOGY OF PART OF THE TOWNSEND VALLEY BROADWATER AND JEFFERSON COUNTIES, MONTANA}

\author{
By V. L. Freeman, E. T. Ruppel, and M. R. KLepper
}

\begin{abstract}
The Townsend Valley, a broad intermontane basin in west-central Montana, extends from Toston to Canyon Ferry. The area described in this report includes that part of the valley west of longitude $111^{\circ} 30^{\prime} \mathrm{W}$. and south of latitude $46^{\circ}$ $30^{\prime} \mathrm{N}$. and the low hills west and south of the valley. The Missouri River enters the area near Townsend and flows northward through the northern half of the area. Three perennial tributaries and a number of intermittent streams flow across the area and into the river from the west.

The hilly parts of the area are underlain mainly by folded sedimentary rocks ranging in age from Precambrian to Cretaceous. The broad pediment in the southwestern part is underlain mainly by folded andesitic volcanic rocks of Upper Cretaceous age and a relatively thin sequence of gently deformed tuffaceous rocks of Tertiary age. The remainder of the area is underlain by a thick sequence of Tertiary tuffaceous rocks that is partly blanketed by late Tertiary and Quaternary unconsolidated deposits. Two units of Precambrian age, 13 of Paleozoic age, 7 of Mesozoic age, and several of Cenozoic tuffaceous rock and gravel were mapped.
\end{abstract}

Rocks of the Belt series of Precambrian age comprise a thick sequence of siltstone, sandstone, shale, and subordinate limestone divisible into the Greyson shale, the Spokane shale, and the basal part of the Empire shale, which was mapped with the underlying Spokane shale.

The Precambrian rocks are overlain with slight angular unconformity by a parallel-bedded sequence of Paleozoic and Mesozoic sedimentary rocks. The formations of Cambrian age, named from oldest to youngest, are the Flathead quartzite, Wolsey shale, Meagher limestone, and Park shale of Middle Cambrian age, and the Pilgrim dolomite of Late Cambrian age. The uppermost Cambrian unit, the Red Lion formation, and the basal Devonian unit, the Maywood formation of Late Devonian age, are thin units that are difficult to distinguish from one another, and accordingly they were mapped together even though they are separated by an erosional unconformity. The Maywood formation is overlain by the Jefferson dolomite of Devonian age, and the Three Forks shale of Devonian and Mississippian age, and these are overlain by the Lodgepole and Mission: Canyon limestones, subdivisions of the Madison group of Mississippian age. The Amsden formation, which is probably separated from the Mission Canyon limestone by an erosional unconformity of negligible relief, includes rocks of both Mississippian and Pennsylvanian age. It consists of red calcareous siltstone 
with a medial unit of gray carbonate rock and grades into the Quadrant formation of Pennsylvanian age, which consists of interbedded dolomite and quartzite. The Phosphoria formation of Permian age overlies the Quadrant formation and in most places has been mapped with it. The formation, consisting dominantly of chert and quartzite, contains phosphate rock in the southern part of the map area, but farther north phosphatic material is present only as chips and pellets.

Upper Jurassic rocks rest on an erosion surface of very slight relief developed on the Phosphoria formation and grade upward into Lower Cretaceous rocks. The Jurassic rocks comprise the thin marine Swift formation and the relatively thick nonmarine Morrison formation. The Cretaceous sequence consists of the nonmarine Kootenai formation; the Colorado formation, comprising a lower unit of black shale with a basal sandstone, a medial unit of sandstone and siliceous shale, and an upper unit of black shale; the Slim Sam formation, consisting largely of andesitic sandstone; and the Elkhorn Mountains volcanics. In the map area the Elkhorn Mountains volcanics are unconformable on the Slim Sam formation and older rocks, but along the east front of the Elkhorn Mountains several miles to the northwest the Slim Sam formation grades into the volcanics.

The rocks of Tertiary age are mainly sedimentary tuffs of acidic composition. In the northern part of the area one unit of Oligocene age, one of probable Oligocene age, one of Miocene or Pliocene age, and one of uncertain age were mapped. In the southern part of the area all Tertiary rocks are probably of Oligocene age, but the absence of good exposures made it impracticable to subdivide them. The Oliogocene rocks were deposited largely in a lacustrine environment, and Miocene or Pliocene rocks were deposited mainly in a fluviatile environment. The oldest sedimentary tuff, comprising a lower rhyolitic part and an upper bentonitic part, is overlain by a unit composed of bentonitic clays, coarser volcanic debris of probable local origin, and common thin beds of silt, sand, and gravel. The unit of probable Oligocene age is lithologically similar to the units of known Oligocene age. The Miocene or Pliocene sedimentary tuff comprises a lower unit, consisting largely of thick beds of gravel and sandstone, and an upper unit of tuffaceous sediments.

Two map units include sediments of probable late Tertiary and Quaternary age and five map units are of Quaternary age. The late Tertiary and Quaternary sediments comprise a unit of pediment and fan gravels and a unit of flood plain gravel. The Pleistocene and Recent map units are older Pleistocene fan deposits, younger Pleistocene to Recent fan deposits, Recent fan deposits, mantle, and alluvium. Mantle blankets much of the southern part of the map area and smaller areas farther north and comprises terrace gravels, slope wash, silt of probable eolian origin, and small areas of alluvium. Recent clay, silt, sand, and gravel constitute the alluvium along the Missouri River and the smaller streams of the area.

The intrusive igneous rocks include three general types and may be of three different ages. Diabase has been found only as sills in Precambrian rocks and may be late Precambrian in age. Sills, dikes, and partly concordant plutons of diorite porphyry and related rock types are intrusive equivalents of the Elkhorn Mountains volcanics and probably were intruded during the early stages of deformation. A stock of monzonite cutting across folded Elkhorn Mountains volcanics west of Lone Mountain was almost certainly emplaced after the main period of folding and may be of about the same age as the Boulder batholith to the west, probably very late Cretaceous.

The Precambrian rocks were broadly arched and beveled by erosion before Middle Cambrian time. From Cambrian until Late Cretaceous time the area was essentially stable, though several erosional unconformities probably indicate 
epeirogenic movement, or crustal warping on a regional scale. Immediately preceding the outpouring of the Elkhorn Mountains volcanics, in the early part of the Late Cretaceous, the rocks in the southwestern part of the area were gently folded, and subsequent to the outpouring of the volcanic rocks, in the latter part of Late Cretaceous time, all the rocks in the area were strongly folded and faulted. The major structural features formed during this major orogeny were the broad, transversely faulted anticline in the Limestone Hills, the tightly folded and thrust-faulted anticlinorium in the Hossfeldt Hills, including part of the Lombard thrust zone, and the broad syncline west of the Hossfeldt Hills. During one or more periods of Tertiary deformation the mountains bordering the Townsend Valley were uplifted along range-front faults, and the Tertiary rocks in the valley were tilted and cut by faults of relatively small displacement.

Few exploitable metallic mineral deposits have been found within the area. Considerable gold has been recovered from bench gravel and valley-bottom alluvium along Indian Creek and a little has been mined from small lode deposits west of Lone Mountain and in the Limestone Hills. Replacement deposits in limestone about 5 miles west of Lone Mountain have yielded a few thousand tons of lead-zinc ore.

Unexploited channels probably occur in the Indian Creek placer area, and undiscovered lode deposits of gold and of lead and zinc may occur west of Lone Mountain, especially in parts of the area that are blanketed by Tertiary rocks, but the chance of finding large new placer or lode deposits is slight. Low-grade uranium deposits may occur in Tertiary rocks, particularly near the northern boundary and in the southwest part of the area.

Limestone for building stone, quartzite for cement, and gravel for road metal have been mined in the area. Deposits of impure bentonite in Tertiary rocks have not been exploited.

\section{INTRODUCTION}

\section{LOCATION AND EXTENT OF AREA}

The Townsend Valley is described by Pardee $(1925$, p. 1) as "the widened part of the Missouri River between Canyon Ferry and Toston and a broad lowland west of Toston drained by Crow Creek and its tributary Warm Springs Creek." The region described in this report (fig. 50) is that part of the Townsend Valley west of longitude $111^{\circ}$ $30^{\prime} \mathrm{W}$., and south of latitude $46^{\circ} 30^{\prime} \mathrm{N}$. and the hills lying west and south of the valley. It includes the eastern half of the Townsend 15-minute quadrangle and all but the northwest quarter of the Radersburg 15-minute quadrangle.

The described area comprises about 252 square miles in Broadwater County and about 15 square miles in Jefferson County. Townsend, the county seat of Broadwater County with a population of 'about 1,300 , is situated along the Missouri River near the east edge of the area. Helena is 35 miles by road northwest of Townsend.

The Tertiary geology of the Townsend Valley has been described by Pardee (1925), and the part of the Townsend Valley north of the area of this report has been mapped and described by Mertie, Fischer, and Hobbs (1951). The geology and the occurrence of ground water have been described by Lorenz and McMurtrey (1956). 


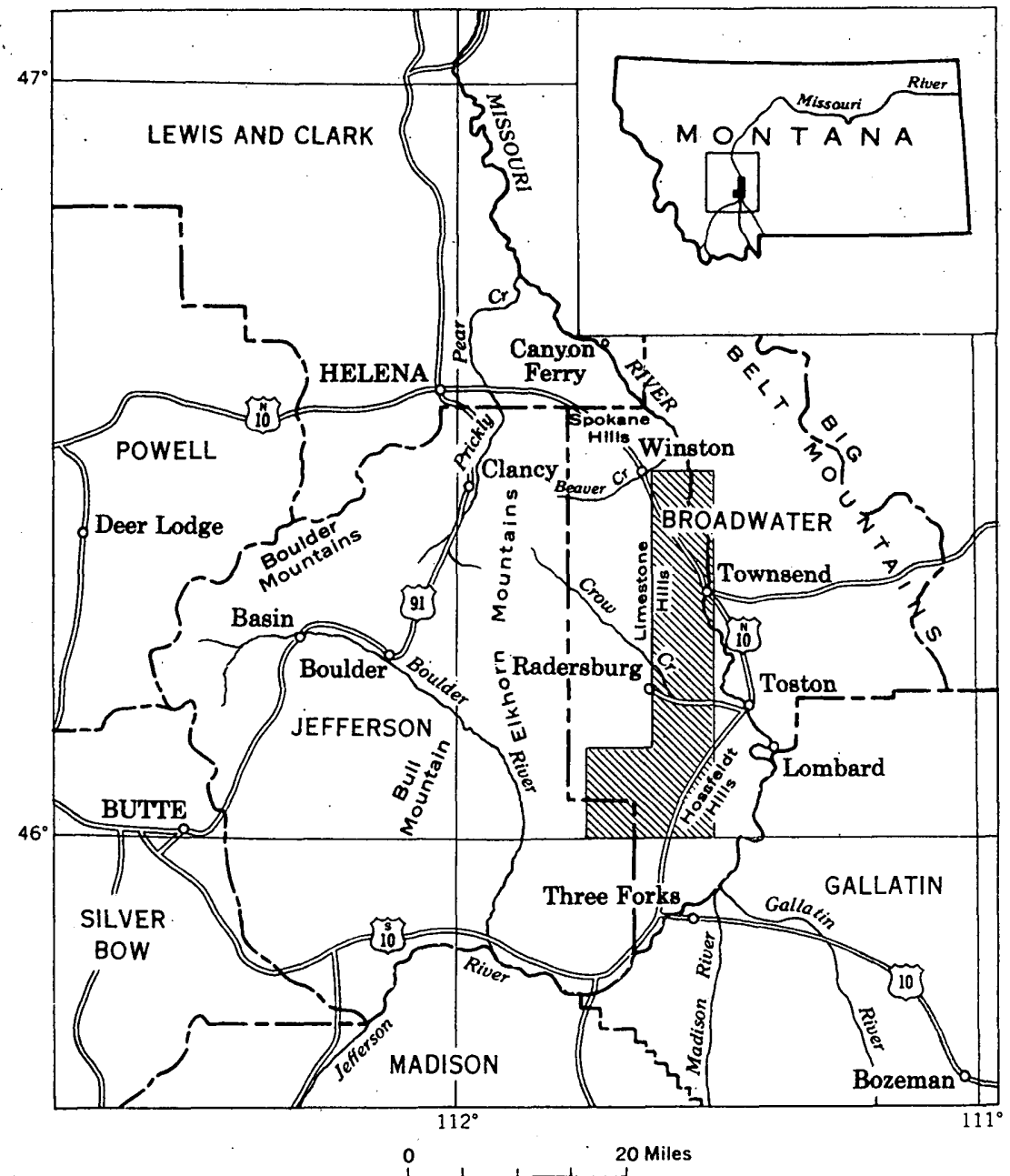

Frgure 50.-Map showing location of the area described in this report.

\section{ACCESSIBILITY}

U. S. highway $10 \mathrm{~N}$ trends southeast from the northivest corner of the area to Townsend at the east margin of the area. After crossing the Missouri River at Toston it trends southwest, and re-enters and crosses the southeastern part of the area. From Toston a paved road extends westward to Radersburg. Maintained county roads are present along Indian Creek, in the Limestone Hills, and in the southwestern part of the area. Unimproved dirt roads provide access to areas away from the paved and maintained roads. No part of the area is more than $1 \frac{1}{2}$ miles from a road traversable in a light truck and it is possible to drive over most of the benchlands and fans. 
A branch of the Northern Pacific Railroad parallels U. S. highway $10 \mathrm{~N}$ from Helena to Toston and from there follows a route up the Missouri River to Logan, a town about 6 miles east of Three Forks.

\section{PURPOSE AND SCOPE OF REPORT}

The Townsend Valley has been mapped as part of a study of the geology and the genesis of ore deposits in and adjacent to the Boulder batholith. Although few important ore deposits are known to exist in the Townsend Valley, geologic mapping has revealed important structural features and has provided much information on the Cenozoic history of the region.

\section{FIELD WORK}

Most of the field work for this report was done during the summer of 1953 by V. L. Freeman. Two small areas aggregating 10 square miles were mapped by M. R. Klepper, one in 1949 and the other in 1952. An area of about 11 square miles in the Limestone Hills was mapped in 1949 by E. T. Ruppel. The parts of the area mapped by each are shown on plate 42 . The sections of this report dealing with stratigraphy, Cenozoic history, and nonmetalliferous deposits were largely written by Freeman and Ruppel, and those dealing with intrusive rocks, structure, and metalliferous deposits largely by Klepper.

The geology mapped in 1953 was plotted on preliminary topographic maps, with a scale of $1: 24,000$, made by Fairchild Aerial Surveys for the U. S. Bureau of Rečlamation. The geology mapped in 1949 was plotted on aerial photographs and transferred to the topographic maps by means of a vertical sketchmaster and a stereoscopic plotter.

Color terms used in the description of rocks are those used in the Rock-Color Chart distributed by the National Research Council. The terminology of fragmental volcanic rocks is that of Wentworth and Williams (1932).

\section{ACKNOWLEDGMENTS}

The authors are indebted to M. Jean Hough and Roland W. Brown of the U. S. Geological Survey, T. E. White of the Smithsonian Institution, and H. M. Sperry of Townsend, Mont. for identification of fossils and for information about the stratigraphy of the Tertiary sedimentary rocks, to R. A. Weeks and H. W. Smedes for aid in the field, to G. D. Robinson for ideas gained during discussions of several aspects of the geology of the area, and to Forbes Robertson and the Montana School of Mines staff for making available the results of student field work in the southeastern part of the Townsend Valley area. 


\section{TOPOGRAPHY}

The Townsend Valley is a north-trending intermontane valley through which the Missouri River flows. The river enters the valley through a narrow canyon a few miles south of Toston, meanders northward across the valley, and exits through a narrow canyon at Canyon Ferry. The Townsend Valley, like other intermontane valleys of western Montana, is at least in part a structural valley. It is bounded by the Big Belt Mountains on the east and the Elkhorn Mountains on the west and is restricted at the north by the Spokane Hills and partly restricted at the south by the Hossfeldt Hills (fig. 50). The Limestone Hills protrude eastward into the valley beyond the general front of the Elkhorn Mountains. The broad lowland south of the Limestone Hills, lying to the southwest of the junction of Crow Creek with the Missouri River, is also considered part of the Townsend Valley (Pardee, 1925).

The Townsend Valley, in the area mapped, consists of an alluviated part and adjacent benchlands covered by generally coarse debris from the adjacent mountains. North of the Limestone Hills, the benchlands consist mostly of riverward-sloping fans formed by streams flowing out of the Elkhorn Mountains. South of the Limestone Hills the benchlands are the remnants of a pediment that has been dissected by tributaries of Warm Springs Creek. The combined fans of Crow Creek and Warm Springs Creek occupy the area between the dissected pediment and the Missouri River.

The total relief within the map area is about 2,250 feet. The altitude ranges from about 3,720 feet on the Missouri River at the north end of the map area to about 5,960 feet on the high point of the Limestone Hills. The part of the Townsend Valley alluviated by the Missouri River ranges in altitude from 3,720 feet to 3,880 feet. The reservoir behind a dam recently constructed (1954) at Canyon Ferry covers, when full, the area below an altitude of 3,800 feet. The benchlands including the fans of Crow and Warm Springs Creeks range in altitude from about 3,800 feet to about 4,800 feet.

The drainage of the northern part of the area is directly into the Missouri River. South of the Limestone Hills the drainage into the Missouri is via Crow and Warm Springs Creeks. The drainage of the extreme southern part of the area is into the Jefferson River.

Within the map area only Confederate Gulch, Indian Creek, Crow Creek, and Warm Springs Creek, which is partly fed by water from Crow Creek, are perennial streams. Most of the flow of Crow Creek is channeled through irrigation ditches within and west of the area mapped. The water of the smaller streams sinks into the porous gravels of the fans or is lost by evaporation except during the spring. 


\section{STRATIGRAPHY}

The sedimentary rocks in the map area range in age from late Precambrian to Recent, with all systems represented except the Ordovician, Silurian, and Triassic. Three formations of Precambrian age belonging to the Belt series are recognized, but two of them were mapped as a single unit. The Paleozoic sequence is composed of 5 formations of Cambrian age, 1 unit containing rocks of both Cambrian and Devonian age, 1 formation of Devonian age, 1 formation of Devonian and Mississipian age, 4 formations of Carboniferous age, and 1 formation of Permian age. The Mesozoic sequence is composed of 2 formations of Jurassic age that were mapped together and 6 mapped units of Cretaceous age. In part of the area the Tertiary deposits were mapped as a single unit, but in places it was possible to recognize and map 4 subdivisions, 2 of Oligocene age, 1 of probable Oligocene age, and 1 of Miocene or Pliocene age. The Quaternary deposits have been subdivided for mapping into 2 units that probably include much late Tertiary sediment and 5 units that are believed to be entirely Quaternary in age.

\section{PRECAMBRIAN ROCKS-BELT SERIES}

The Belt series of Precambrian age is a very thick sequence of interstratified siltstone, sandstone, shale, and limestone. In the vicinity of the Townsend Valley the series has been divided into a number of thick units (Walcott, 1899) of which three, the Greyson shale, the overlying Spokane shale, and the basal part of the Empire shale, are present in the map area. In recent work Ross (oral communication cited by Mertie, Fischer, and Hobbs, 1951, p. 18) has demonstrated that these formations represent only the lower part of the Belt series of Montana.

A regional unconformity at the base of the Paleozoic sequence transects the Belt series so that the Middle Cambrian Flathead quartzite rests on older Beltian rocks at the south end of the Townsend Valley than in the Limestone Hills (pl. 42). In the Canyon Ferry quadrangle to the north (Mertie, Fischer, and Hobbs, 1951), the Belt series consists of, in descending order, the Helena limestone, the Empire shale, the Spokane shale, the Greyson shale, and the Newland limestone. The Flathead quartzite rests on the Helena limestone in the northern part of the Canyon Ferry quadrangle and on the Empire shale in the southern part. In the Limestone Hills the Flathead rests on the basal part of the Empire shale at the north and on the Spokane shale at the south. In the Hossfeldt Hills, at the south end of the Townsend Valley, the Flathead quartzite rests on the Greyson shale. On the west limb of the overturned 
anticline in SE1/4 sec. 7, T. 3 N., R. 2 E., the Flathead clearly truncates beds in the upper part of the Greyson at an angle of about $10^{\circ}$ and rests on progressively older beds to the south.

\section{GREYSON SHALE}

The Greyson shale crops out in a large area on the east flank of the Limestone Hills and in a smaller area in the Hossfeldt Hills, about 12 miles to the south (pl. 42). In both areas the outcrops are generally low and inconspicuous. The exposed thickness of the formation in the Limestone Hills is between 2,500 and 3,000 feet, including a gradational zone several hundred feet thick at the top. The exposed thickness in the Hossfeldt Hills is considerably less. The base of the formation is not exposed in either of these areas. In the Canyon Ferry quadrangle the formation is between 2,000 and 3,000 fect thick (Mertie, Fischer, and Hobbs, 1951, p. 19).

Although the Greyson shale was mapped as a single unit, it comprises three rather distinctive parts. The lowest part, about 1,300 feet thick, is exposed in the Limestone Hills and consists of olivecolored very thin bedded silty shale, siltstone, and minor fine-grained sandstone; this part of the formation includes many beds of thinto thick-bedded yellowish-gray siltstone at the top. Overlying the thick-bedded siltstone, which is the most resistant part of the Greyson shale, is about 1,050 feet of grayish-olive-green shale, partly silty, that is much less resistant to weathering. The contact between the siltstone and the shale is easily discernable on the topographic map. This thick shale unit is the lowest part of the Greyson shale exposed in the Hossfeldt Hills. Overlying the thick shale unit and grading upward into the Spokane shale is a sequence several hundred feet thick of yellowish-gray siltstones and very fine grained sandstones, grayish-green argillites, grayish-red argillites, clean fine- to mediumgrained quartzites, and a few granular and algal limestones. Red shale, quartzite, and limestone become more abundant toward the top of the formation. The contact between Greyson shale and Spokane shale in the Townsend Valley area was mapped where the rocks change from predominantly green and yellowish gray to predominantly red; in the southern Elkhorn Mountains a few miles to the west, it was mapped a few hundred feet lower at the lowest conspicuous red bed (Klepper, Weeks, and Ruppel, 1957).

In the Limestone Hills the color change is stratigraphically lower at the south end than at the north end. In the Hossfeldt Hills no Spokane shale was mapped, although a thin zone of rocks below the Flathead quartzite is predominantly reddish. The abundance of quartzite and limestone in this reddish zone indicates that the Flathead quartzite is resting on beds about at the contact between the Greyson 
and Spokane shales. The color change here is apparently stratigraphically lower than in the southern part of the Limestone Hills. Two measured sections of the Greyson shale, in which the lithologyr of the formation is described in more detail, are included in the part of this report entitled "Stratigraphic sections."

The Greyson shale seems to represent a transition from deposition at moderate depth to deposition at shallow depth. Sandstone and quartzite beds and ripple marks and crossbedding are more abundant in the upper part, and granular and algal limestones are present only near the top of the formation.

The rocks of the Greyson shale have been colored by deep weathering to shades of pale orange in the northern part of the Hossfeldt Hills and at the northern end of the Limestone Hills. This deep weathering probably occurred in late Tertiary time beneath erosion surfaces that formed in these areas.

\section{BPOKANE SHALE}

The Spokane shale crops out in a broad belt in the Limestone Hills west and south of the Greyson shale. Outcrops are generally very low and inconspicuous, but exposure is good due to the poor development of soil. In the northern part of the Limestone Hills the Spokane shale is about 4,000 feet thick and in the southern part of the Limestone Hills it is about 5,000 feet thick. (See "Stratigraphic sections.") In the Canyon Ferry quadrangle the Spokane shale is between 1,500 and 2,000 feet thick (Mertie, Fischer, and Hobbs, 1951, p. 19), and in the southern Elkhorn Mountains about 1,700 feet thick (Klepper, Weeks, and Ruppel, 1957). In the Hossfeldt Hills it is absent or only a few tens of feet thick. Its relatively great thickness in the Limestone Hills is probably due partly to lateral gradation of the Spokane shale into the Empire shale as demonstrated by Klepper, Weeks, and Ruppel (1957) but probably due mostly to original greater thickness in this area.

The Spokane shale was mapped as a single unit but three rather distinctive parts were recognized. The basal part, about 1,200 feet thick, consists dominantly of grayish-red thin- and even-bedded siltstone and argillite. A few beds of quartzite and limestone, one-half to 3 feet thick, are present, especially near the base, and greenishgray argillite and siltstone beds are locally present. The central part. of the formation, about 1,000 feet thick, consists principally of dark purple siltstone and argillite but includes some grayish-green beds. This zone has been intruded by a series of en echelon sills. Near the : base of this zone is a 1- to 4-foot-thick partly granular argillaceous limestone bed, probably of algal origin. The upper part of the Spokane shale is 2,000 to 3,000 feet thick and consists dominantly of grayish-red siltstone and argillite that resembles the lower part. 
Very thin units of white sandstone, grayish-red quartzite, and greenish-gray argillite are also present. Two measured sections of the Spokane shale are included in the stratigraphic sections given in the back of this report.

\section{FMPIRE SHAITE}

The Empire shale is present only in the northern part of the Limestone Hills. Because the formation is thin and poorly exposed, it is included with the underlying Spokane shale on plate 42 . Its thickness is about 100 feet at the northernmost exposures, increases to about 160 feet thick a mile to the south, and then gradually decreases in thickness and disappears $1 \frac{11}{2}$ miles farther to the south because of pre-Flathead erosion. The Empire shale consists of dark-gray laminated siltstone and argillite that weathers greenish gray. Beds that resemble the Empire are interbedded in the upper 100 feet of Spokane shale.

\section{CAMBRIAN ROCKS}

The earliest work on the Cambrian rocks of Montana was done by A. C. Peale (1893, p. 20-25) in the Three Forks region, which adjoins the Townsend Valley area to the south and southeast. He divided the Cambrian strata into two formations-tne Flathead formation, consisting of (ascending) the Flathead quartzite and the Flathead shales, and the Gallatin formation, consisting of (ascending) the trilobite limestones, Obolella shales, mottled limestones, Dry Creek shales, and pebbly limestones. The present nomenclature of Cambrian rocks in central and southwestern Montana is based on rocks in the Little Belt Mountains described by Weed (1900, p. 284-287): Weed divided the Cambrian rocks in that area into seven formationsthe Flathead quartzite, Wolsey shale, Meagher limestone, Park shale, Pilgrim dolomite, Dry Creek shale, and Yogo limestone, in ascending order. This classification was later emended by Deiss (1936, p. 1317-1342), who redefined the lower six formations and eliminated the seventh, the Yogo limestone, which is probably equivalent, at least in part, to strata now included in the Devonian (Sloss and Laird, 1947, p. 1415). Deiss' emended classification, based on exposures of Cambrian rocks in the central Montana-Yellowstone Park region, is followed in this paper, except for the uppermost Cambrian unit, here called the Red Lion formation (Emmons and Calkins, 1913, p. 61-63). Hanson (1952) describes the lithology and the correlation of the Cambrian rocks in southwestern Montana and adjacent areas and gives a complete annotated bibliography.

In the Limestone Hills the Cambrian rocks have a thickness of. about 1,700 feet; in the Hossfeldt Hills, about a mile east of the map area, a measured section of the Cambrian rocks is about 1,500 feet thick. (See "Stratigraphic sections.") As well as can be determined, 
the Cambrian rocks represent a conformable sequence. The Flathead quartzite, Wolsey shale, Meagher limestone, and Park shale are of Middle Cambrian age and the Pilgrim dolomite and Red Lion formation, which is mapped with the Devonian Maywood formation as a unit, are of Late Cambrian age.

\section{FLATHEAD QUARTZITE}

The Flathead quartzite forms a low ridge trending north through the Limestone Hills where it is 100 to 120 feet thick (Klepper, Weeks, and Ruppel, 1957). In the Hossfeldt Hills the formation is 25 to 50 feet thick and locally forms an inconspicuous ridge.

The Flathead quartzite is composed of thin irregular commonly cross-laminated beds of orthoquartzite with very few thin beds of shale and siltstone. It ranges from white to grayish red on fresh surfaces and weathers to a somewhat darker color; specks of brown iron oxide are present locally. Quartz grains make up about 98 percent of the rock; black and red opaque grains, tourmaline, zircon, and muscovite grains (in order of decreasing abundance) are also present. The average grain size of the individual beds ranges from silt to coarse sand, and the grains of individual beds are generally moderately well to well sorted. The grains appear to have been originally subrounded to rounded, but overgrowths of quartz have destroyed their rounded nature and have strongly cemented the rock. Granules and pebbles are present locally in small lenses or scattered throughout the coarser beds. Locally a basal pebble zone occurs in the Limestone Hills; many of the pebbles in this zone were derived from the underlying Belt series.

\section{WOLSEY SHALE}

The Wolsey shale crops out in a north-trending band in the Limestone Hills and in a folded band in the Hossfeldt Hills. It is more easily eroded than the underlying and overlying formations and forms a swale with very few outcrops. It is about 380 feet thick throughout the area. (See "Stratigraphic sections.")

The Wolsey sbale is gradational with the underlying Flathead quartzite and contains, near its base, a few thin sandstone and quartzitic sandstone beds that resemble the Flathead quartzite except for a small but noticeable content of glauconite gr-ins and abundant small specks of limonite probably formed by oxidation of glauconite. The bulk of the Wolsey shale is composed of greenishgray and olive-colored locally silty shale and mudstone. Thin beds of limestone and limy siltstone also are common in the upper half of the formation west of the map area (Klepper, Weeks, and Ruppel, 1957), but similar beds are rare or absent in the Limestone Hills 
and, as far as is known, in the Hossfeldt Hills. Middle Cambrian fossils are common in the formation.

The Wolsey shale grades into the overlying Meagher limestone in the adjacent soutbern Elkhorn Mountains (Klepper, Weeks, and Ruppel, 1957), but in the Limestone Hills the contact appears to be sharp rather than gradational. Because of poor exposures, the nature of the contact is not known in the Hossfeldt Hills.

\section{MEAGHER LMMESTONE}

The Meagher limestone crops out along a north-trending ridge in the Limestone Hills and as a folded band, locally forming a ridge, in the Hossfeldt Hills. It is about 500 feet thick in the Limestone Hills (Klepper, Weeks, Ruppel, 1957) and about 360 feet thick in the Hossfeldt Hills.

In the Limestone Hills the formation can be divided into three fairly distinct though gradational units. The basal unit is about 120 feet thick and consists of conspicuously mottled and banded gray limestone. The mottling and banding is brownish gray to brownish black near the base but gradually changes upward and is dark yellowish orange and yellowish gray near the top. The middle unit is about 150 feet thick and consists of gray locally oolitic thick-bedded to massive limestone, in part mottled or banded with darker shades of gray. This is commonly the most resistant unit of the formation. The upper unit is mottled and banded thin- to medium-bedded limestone ( $\rho l .43$, $A$; pl. 44), somewhat similar to the lower unit, and is about 235 feet thick. The lower 100 feet of this upper unit is inconspicuously mottled yellowish gray; the upper 135 feet is conspicuously mottled yellowish orange.

In the Hossfeldt Hills the Meagher limestone can be divided into two units. The lower unit, about 325 feet thick, consists of dark-gray limestone with olive-gray banding less than one-fourth inch thick paralleling the bedding. The banding is discontinuous in the upper half of the unit. The upper unit is about 35 feet thick and consists of dark-gray limestone with grayish-orange mottles that cut the bedding. Abundant fossil fragments and a few pyrite cubes are present in the upper unit. A measured section of the Meagher limestone in the Hossfeldt Hills is included in the section on stratigraphic sections.

The light-colored irregular mottles and ribbons in the Meagher limestone in the map area are commonly dolomitic, slightly silty, and more coarsely crystalline than the enclosing limestone. The darkcolored part forms the bulk of the rock and is finely crystalline pure limestone. An analysis of the light- and dark-colored parts of the rock, furnished by the Vermont Marble Co., is as follows: 


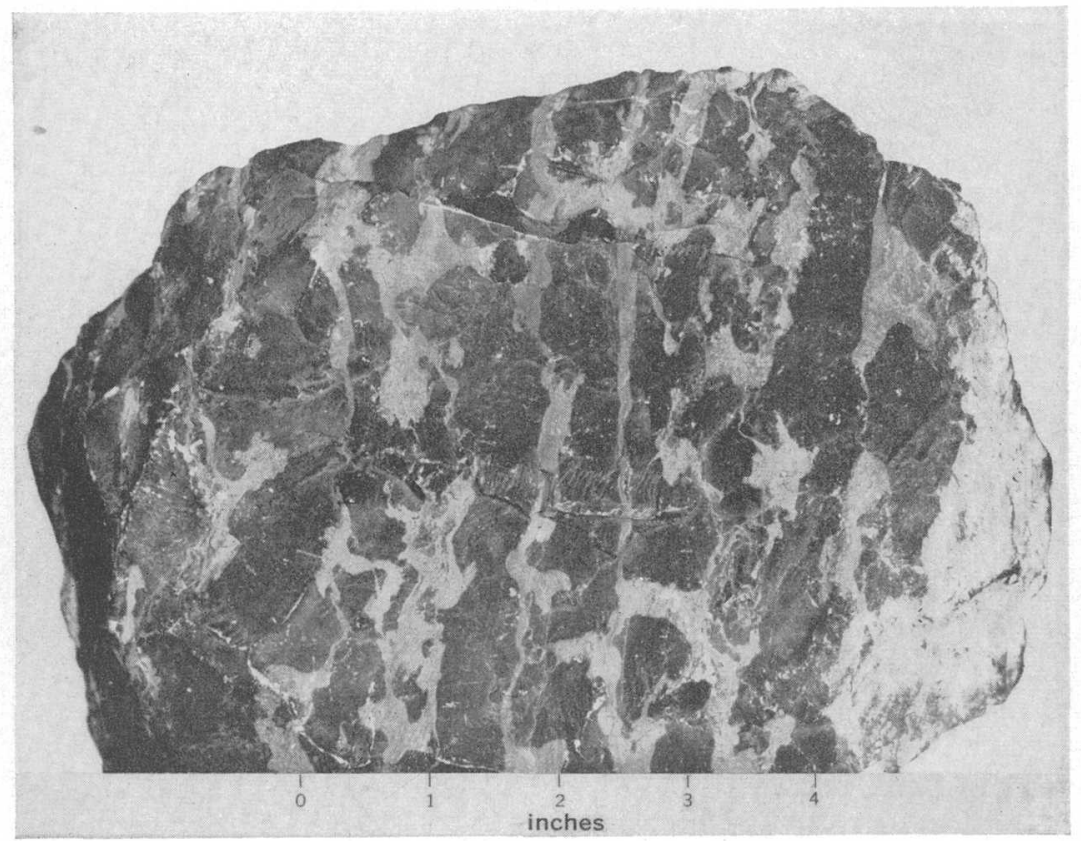

A. Meagher limestone, upper part. Dark color is dense medium-gray pure limestone. Light color is somewhat coarser grained yellowish-orange slightly calcitic dolomite. Elongation of mottles parallels bedding.

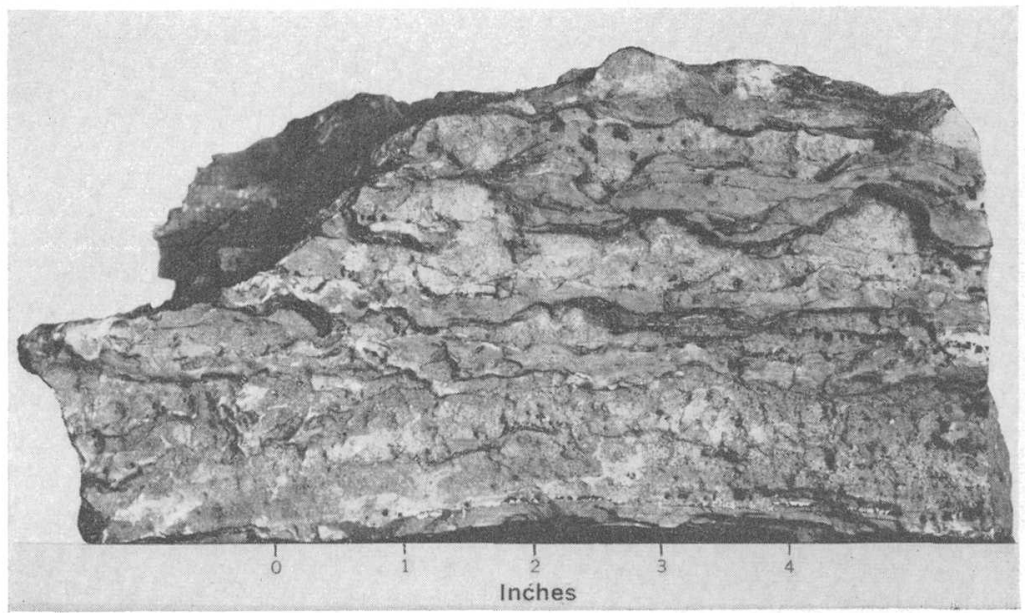

B. Pilgrim dolomite. Sample of dolomite unit showing conspicuous ribbons of yellowish-orange silty calcitic dolomite weathering in relief in gray dolomite.

Typical specimens of Meagher limestone and Pilgrim dolomite showing mottling. 


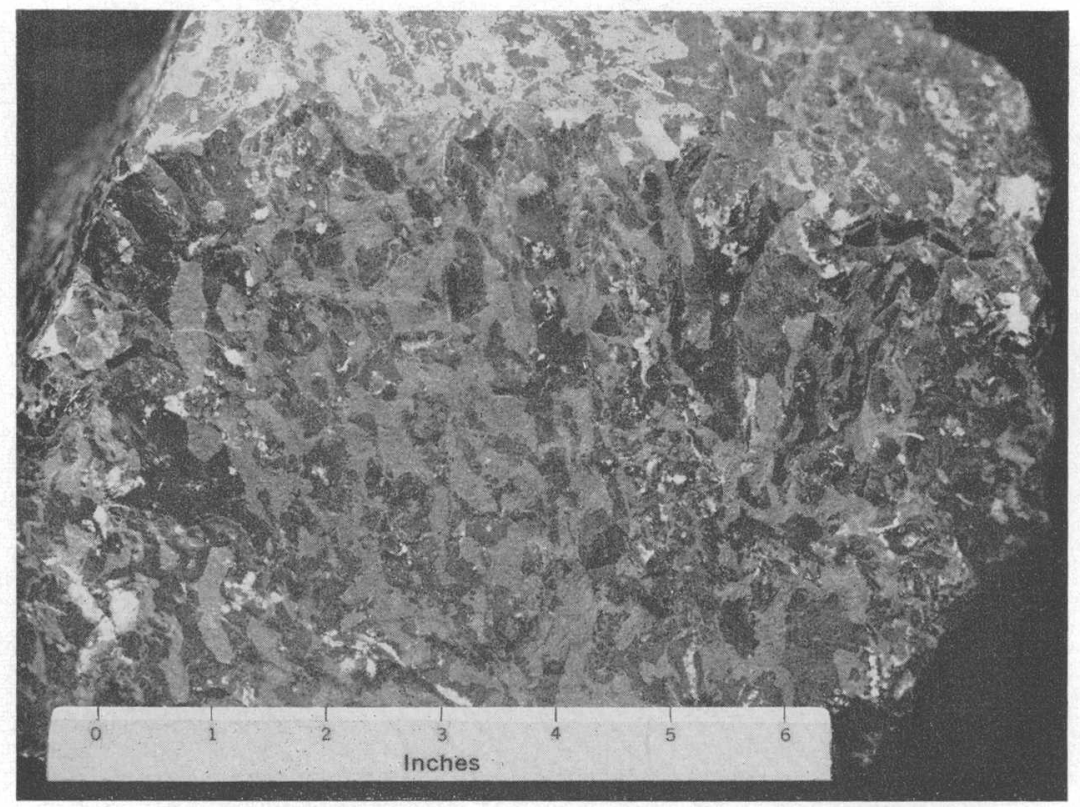

Typical specimen of Meagher limestone. 


\begin{tabular}{|c|c|c|}
\hline & $\begin{array}{l}\text { Light-colored mottles } \\
\text { (percent) }\end{array}$ & $\begin{array}{l}\text { Dark-colored matrix } \\
\text { (percent) }\end{array}$ \\
\hline $\begin{array}{l}\text { Insoluble }\left(\mathrm{SiO}_{2}\right) \\
\text { Jron and aluminam } \\
\mathrm{CaCO}_{3}(\mathrm{CaO}) \\
\mathrm{MgCO}_{3}(\mathrm{MgO})\end{array}$ & $\begin{array}{l}\text { 14. } 00 \\
\text { 3. } 30 \\
\text { 55. } 34(31.00) \\
25.50(12.20)\end{array}$ & $\begin{array}{r}4.75 \\
2.18 \\
90.14(50.5) \\
2.60(1.25)\end{array}$ \\
\hline Total & 98. 14 & 99. 67 \\
\hline
\end{tabular}

No allowance made for alkalies or moisture.

Specimen from upper part of Meagher limestone, Limestone Hills, Broadwater County, Montana.

Analyst: Hartzell, Montana School of Mines.

Thin-section study of samples from the upper part of the Meagher in the Limestone Hills shows that the contacts between light- and dark-colored parts of the rock are generally gradational and that zoned dolomite crystals are restricted to the light-colored part. The dark-colored part is almost entirely finely crystalline calcite. The writers believe that the light- and dark-colored parts are primary features of the rock, resulting from fluctuating physical conditions at the time of deposition. A possible interpretation is that dark-colored lime mud accumulated in a reducing environment during periods of relative calm, and light-colored dolonitic material was formed in an oxidizing environment, perhaps during periods of strong wave and current action. The zoned dolomite crystals suggest that the high dolomite content of the mottles is due to replacement of calcite by magnesia-containing solutions, probably sea water acting on newly deposited impure limy sediments in an oxidizing environment resulting from turbulent seas.

Similar features in the Palliser limestone of Alberta are considered by Beales (1953, p. 2281-2293) to be the result of local replacement of original limestone, possibly magnesian, by dolomite at an early stage in diagenesis. He suggests that the replacement was controlled by local variations in effective diffusion porosity in the sediments. The conspicuous mottling is considered to be due to secondary alteration and recrystallization.

\section{PARK SHALE}

The Park shale is concealed in the map area and commonly forms a swale between the Meagher limestone and the Pilgrim dolomite. The thickness of the Park shale varies considerably, probably because of deformation. In the Limestone Hills the thickness is typically 200 to 250 feet and in the Hossfeldt Hills about 300 feet. Fragments found in the mantle overlying the Park shale indicate that it consists largely of olive-green fissile shale that appears waxy. 


\section{PILGRIM DOLOMITE}

The Pilgrim dolomite crops out in a north-trending band in the Limestone Hills and as a folded band in the Hossfeldt Hills. It also forms two small cuestas southeast of Plunket Lake. The Pilgrim dolomite is a resistant unit that usually forms a ridge and is well exposed. In the Limestone Hills it is about 420 feet thick (Klepper, Weeks, and Ruppel, 1957) and in the Hossfeldt Hills it is about 350 feet thick.

The Pilgrim dolomite in the Limestone Hills can be divided into four lithologic units. The basal unit is about 25 feet thick and consists of finely crystalline massive gray limestone. On weathered surfaces, it is inconspicuously mottled lighter gray. This unit grades into the overlying unit, which is about 165 feet thick and consists of gray limestone ribboned and mottled with yellowish silty calcitic dolomite or dolomitic limestone (pl. $43, B$ ). The third unit, gradational with the ribboned limestones below, is about 80 feet thick and consists of medium-light- to medium-dark-gray fine- to mediumcrystalline locally oolitic dolomite that is irregularly mottled lighter gray. This mottling, which is readily apparent only on the weathered surface, is distinctly planar and more or less parallel to the bedding in the upper half of the unit. Thin beds of intraformational conglomerate are fairly common in this unit. The fourth and uppermost unit is gradational with the upper part of the third unit and is about 150 feet thick. It consists of light-gray medium-crystalline massive homogeneous dolomite. This uppermost unit forms a conspicuous ridge that extends the length of the Limestone Hills.

The Pilgrim dolomite is 333 feet thick in a section in the Hossfeldt Hills about a mile east of the map area. (See "Stratigraphic sections.") The formation is divisible into three units. The lower 32 feet of the formation consists chiefly of finely crystalline dolomitic limestone that is mostly dark olive gray with some yellowish coloration in which faint mottling can be detected, and includes a few thin beds of oolitic limestone. The middle unit is 132 feet thick and consists of poorly exposed yellowish-gray to medium-gray very finely crystalline limestone with ribbons of grayish-yellow limestone one-half to threefourths inch thick. The unit is thin bedded at the base becoming thick bedded and dolomitic near the top. Glauconite grains were observed in some pieces of float from this unit. The third and uppermost unit is 169 feet thick and consists of a lower part, 120 feet thick, and an upper part 49 feet thick. The lower part consists of deep-olive-gray mottled yellowish-gray medium-crystalline dolomite. The upper part is like the lower except that the mottling is very indistinct; it resembles the upper unit in the Limestone Hills, but is much thinner. 
The middle unit of the Pilgrim dolomite in the Hossfeldt Hills is variable in thickness and composition and is generally poorly exposed. It contains many thin beds of silty limestone or dolomite; float from these beds cannot be distinguished readily from float of the Red Lion and Maywood formations. The upper unit of the Pilgrim dolomite in this area is typically a massive gray dolomite with conspicuous darker gray mottling. Along the outcrop forming the westernmost of the two cuestas southeast of Plunket Lake, the unit changes abruptly to the light-gray homogeneous appearance that it has in the Limestone Hills. The reason for this abrupt change is not apparent.

\section{CAMBRIAN AND DEVONIAN ROCKS}

\section{RED UION AND MAYWOOD FORMATIONS}

Between the Pilgrim dolomite and the Jefferson dolomite is a poorly exposed thin unit that is here referred to as the Red Lion and Maywood formations following recent studies in this region (Hanson, 1952; Klepper, Weeks, and Ruppel, 1957). This unit in the past has been considered as the Cambrian Dry Creek shale of Peale (1893), but work by Sloss and Laird (1947) and Lochman (1950) clearly demonstrates that the unit contains rocks of both Cambrian and Devonian age. Because the name Dry Creek has been used in three senses (Lochman, 1950), the terminology used in the Philipsburg quadrangle (Emmons and Calkins, 1913), where similar rocks have been clearly described, is followed in this report. The Red Lion formation of Cambrian age and Maywood formation of Devonian age were mapped as a unit in the present study even though the two formations are separated by an erosional unconformity. This mapping procedure was adopted because the formations are thin and somewhat similar in lithology and because in most places they are too poorly exposed to permit accurate placement of the unconformity.

The Red Lion and Maywood formations form a narrow swale in the Limestone Hills, where they are about 110 feet thick, and also in the Hossfeldt Hills, where they range from about 10 to 100 feet in thickness. About a mile east of the map area they are about 180 feet thick. Two measured sections are included in the stratigraphic sections.

In the Limestone Hills, rocks of the Red Lion and Maywood interval can be divided into two units. The lower unit is 35 to 50 feet thick and consists mainly of reddish siltstones, with some thin interbedded dolomite beds. The upper unit is 40 to 60 feet thick and consists dominantly of light-colored in part faintly mottled limestone and dolomite, some beds of which are silty or contain siltstone chips and partings. The lower unit is probably entirely Red Lion formation and the upper unit is mostly, if not entirely, Maywood formation. 
In the southeastern part of the mapped area the zone is comprised of very thin to thin-bedded pale-yellow to pale-red silty limestone and limy siltstone and light-olive-gray silty shale.

\section{DEVONIAN ROCKS}

The Devonian of central and southwestern Montana was first studied in detail by A. C. Peale in 1893. Peale's work in the Three Forks region (1893, p. 27-32) resulted in the division of Devonian rocks in Montana into two formations, the Jefferson dolomite and the overlying Three Forks shale. This stratigraphic division is still accepted, however, the age of the Three Forks shale has more recently been designated as Devonian and Mississippian. Sloss and Laird (1947, p. 1413-1415) have since defined, in the Three Forks region, a basal Devonian unit, probably equivalent to the Maywood formation of this paper.

\section{JEFFERSON DOLOMITE}

The Jefferson dolomite crops out in a north-trending band in the Limestone Hills and in a discontinuous band in the southeastern part of the mapped area. It is about 500 feet thick in the Limestone Hills and forms a conspicuous ridge. In the Hossfeldt Hills it is nearly 600 feet thick but does not form a definite ridge.

The formation is composed of very thin to thick-bedded mediumgray to dark-gray fetid dolomite that weathers brownish gray, and of a subordinate amount of limestone that weathers light gray. Other characteristic features include the presence of a few chert concretions. and breccia zones that are parallel to the bedding and are probably of sedimentary origin. The Jefferson dolomite is apparently conformable with both the underlying Maywood formation and the overlying Three Forks shale. A section of the Jefferson dolomite measured in the Hossfeldt Hills is included in Stratigraphic sections.

\section{DEVONIAN AND MISSISSIPPIAN ROCKS}

\section{THREE FORKS SHALE}

The Three Forks shale crops out in two poorly exposed narrow bands bordering the thick sill in the Limestone Hills (pl. 42), in a poorly exposed band south of Plunket Lake, and in the extreme southeast corner of the map area. In the Limestone Hills the formation is about 360 feet thick. (See "Stratigraphic sections.") The lower 280 feet consists of gray very fissile shale some of which weathers to paper-thin fragments and some to pencil-like fragments. The upper 80 feet consists almost entirely of yellowish-gray calcareous siltstone with subordinate beds of light-gray silty limestone. South of Plunket Lake no estimate of thickness could be obtained because 
of poor exposures; in this area the formation is composed of grecnishgray shale containing limy concretions as much as 18 inches in diameter, very thin to thin-bedded fossiliferous yellowish-gray limy siltstone, and a bed of limestone about 3 feet thick.

\section{CARBONIFEROUS ROCKS}

\section{MADISON GROUP}

The Madison limestone was named and first described by A. C. Peale (1893, p. 32-39), who considered it a formation and divided it into three lithologic units-the laminated limestones, the massive limestones, and the jaspery limestones in ascending order. These three units were later correlated by Weed (1900, p. 290-294) with the lower Carboniferous Paine shale, Woodhurst limestone, and Castle limestone of central Montana. The formation was named for the Madison Range, where it is conspicuously exposed.

The Madison limestone in the vicinity of the Little Rocky Mountains was raised to the status of a group by Collier and Cathcart (1922, p. 173) and subdivided into two formations-the Lodgepole and the Mission Canyon limestones, both of Early Mississippian age. The lithology of the Madison group in the Townsend Valley is similar to that described by Collier and Cathcart, and accordingly the writers have followed Collier and Cathcart's terminology.

James Steele Williams made tentative field identifications of Late Mississippian fossils from the upper 150 to 200 feet of the Mission Canyon limestone in the $\mathrm{SE} 1 / 4$ sec. 29 , T. 6 N., R. 1 E., indicating that this part of the Mission Canyon in the Limestone Hills may be equivalent in age to part of the Late Mississippian Brazer limestone of northeastern Utah (Richardson, 1913, p. 413).

\section{LODGEPOLE LIMESTONE .}

The Lodgepole limestone crops out in north-trending belts in the Limestone Hills and south of Plunket Lake. Small exposures are also present east of U.S. highway $10 \mathrm{~N}$ along the southern edge of the map area, and about 5 miles west of Lone Mountain at the western margin of the map area. In the Limestone Hills, where it ranges from 600 to 650 feet in thickness (Klepper, Weeks, and Ruppel, 1957), the Lodgepole limestone overlies the Three Forks shale with apparent conformity. It consists mainly of gray thin- to mediumbedded limestone, many beds of which are fossiliferous. The upper part of the formation is gradational, through a thickness of at least 50 feet, into the massive limestone of the Mission Canyon, and placement of the contact is therefore interpretive. 


\section{MISSION CANYON IIMESTONE}

The Mission Canyon limestone crops out in the Limestone Hills, south of Plunket Lake, and along the western edge of the map area 5 miles west of Lone Mountain. In the southern part of the Limestone Hills, the Mission Canyon is about 1,100 feet thick.

Throughout the mapped area, the Mission Canyon limestone consists of medium-gray to light-gray, finely to coarsely crystalline, usually thick- and indistinctly bedded or massive limestone. West of Plunket Lake, the upper part is locally thin bedded and contains silicified fossils. Solution breccias are common in the upper third of the formation; most of them appear lenticular, but some lenses may have considerable lateral extent. Concretions of chert are present but not abundant; some beds contain fairly abundant thin siliceous encrustations that surround limestone cores, weather in relief, and closely resemble chert.

The limestone characteristically weathers to an extremely rough surface which may be pitted or grooved by solution channels that parallel the direction of slope and which may be more than an inch deep.

\section{AMSDEN FORMATION}

The Amsden formation was named by N. H. Darton (1904, p. 396-397) for exposures near Dayton, Wyo., but was not recognized in the central Montana-Yellowstone Park region until 1935 (Scott, 1935, p. 1013-1014). Prior to 1935, the formation in this region had been included in the overlying Quadrant formation of Pennsylvanian age in accordance with Peale's description of the Quadrant formation in the Three Forks region (1893, p. 39-43) and the description of the Quadrant at its type locality on Quadrant Mountain in Yellowstone Park (Weed, 1896, p. 5). The formation includes rocks of Mississippian and Pennsylvanian age in the central Montana-Yellowstone Park region.

Scott (1935, p. 1023) determined the age of the Amsden formation as latest Mississippian (middle or late Chester), but Berry (1943, p. 19) has since identified fossils of Pennsylvanian age from the upper 100 feet of the Amsden in the Three Forks-Logan area. It is probable that the upper part of the formation in the Three Forks-Yellowstone Park region and in the Townsend Valley is of Pennsylvanian age.

The Amsden formation is present in the map area near the north and south ends of the Limestone Hills, about 5 miles west of Lone Mountain, and southwest of Plunket Lake. In the Limestone Hills it is about 260 feet thick. (See "Stratigraphic sections.") - It overlies the Mission Canyon limestone, probably on an erosion 
surface of slight relief (Klepper; Weeks, and Ruppel, 1957), and grades upward into the Quadrant formation through a thickness of about 60 feet. The upper contact was placed at the lowest bed of vitreous quartzite or, if exposures were poor, at the upper limit of reddish siltstone float and reddish soil; 'the lowest quartzite bed and the upper limit of reddish soil are at about the same stratigraphic position.

The best exposures of the Amsden formation are in the Limestone Hills. Here it consists of reddish commonly calcareous siltstone with a conspicuous 35 -foot thick limestone and dolomite unit 75 to 110 feet below the top of the formation. The formation is generally poorly exposed and characteristically forms a swale between the resistant Mission Canyon limestone and the quartzite of the Quadrant formation.

\section{QUADRANT FORMATION}

The Pennsylvanian rocks of southwestern Montana were first studied in the vicinity of Three Forks, where the name Quadrant was applied to all the rocks between the Mississippian Madison limestone and the Jurassic Ellis formation (Peale, 1893, p. 39-43). However, the Quadrant was not defined at its type locality on Quadrant Mountain in Yellowstone Park until 1896 (Weed, 1896, p. 5). Weed's definition of the formation included only rocks between the Madison limestone and the Permian and Triassic Teton formation, but Peale's original definition continued to be applied in the Three Forks - Yellowstone Park region until 1918, when Condit (1918, p. 113) restricted the formation to the rocks lying between the Madison limestone and the Phosphoria formation of Permian age. Scott (1935, p. 10131014) further restricted the Quadrant formation by assigning the name Amsden to the basal 109 feet of the formation at its type locality.

In the Townsend Valley the formation is gradational with the underlying Amsden formation. It crops out in the western part of the Limestone Hills, about 5 miles west of Lone Mountain, and southwest of Plunket Lake. In the Limestone Hills the formation is about 325 feet thick and consists of alternating yellowish-brown quartzite and quartzitic sandstone and gray locally cherty dolomite beds. Dolomite is dominant in the lower half of the formation and quartzite in the upper half. The quartzites are clean very fine to fine-grained orthoquartzites strongly cemented by overgrowths of quartz on the original quartz grains. The Quadrant formation is thin to thickbedded with inconspicuous crossbedding in some beds. The quartzites exposed in low outcrops southwest of Plunket Lake are dark brownish gray, possibly due to weathering. 


\section{PERMIAN ROCKS}

PHOSPHORIA FORMATION

Permian rocks in the area from northeastern Utab to southwestern Montana are assigned to the.Phosphoria formation. This formation which was first described and named by Mansfield and Richards (1912, p. 684-689) from its exposure in Phosphoria Gulch, near Meade Park, Idaho, has since been recognized over a considerable area in southwestern Montana. The formation thins to a featheredge to the northeast of a line from about Helena, Mont. to Yellowstone National Park (Condit, 1918, p. 113; Swanson, McKelvey, and Sheldon, 1953, p. 2). The Townsend Valley lies near this edge of the formation. Because of the thinness of the formation in the map area, it was generally mapped with the Quadrant formation that underlies it with apparent conformity. In the northwestern part of the Limestone Hills the two formations were mapped separately.

The Phosphoria formation crops out along the western edge of the Limestone Hills, about 5 miles west of Lone Mountain, and about 1 mile southwest of Plunket Lake. About 1 mile west of the soutbwestern corner of the map area, the formation is about 125 feet thick and consists of yellowish-brown chert and light-brown, in part crossbedded quartzite and sandstone. The lower part contains 2 thin phosphatic zones separated by about 20 feet of chert; the lowest zone is about 1 foot thick and consists of phosphatic sandstone and interbedded phosphate rock; the upper zone is about 4 feet thick and includes two 1 - to 2 -foot-thick beds of phosphate rock separated by about one-half foot of phosphatic mudstone (Klepper, Weeks, and Ruppel, 1957). Three miles to the northeast, in sec. 29 , T. 4 N., R. 1 W., in the area of this report, the formation is about 45 feet thick and consists of interbedded chert, sparsely phosphatic sandstone, quartzite, and one bed of phosphate rock less than a foot thick. Farther to the northeast, along the western edge of the Limestone Hills (Klepper, Weeks, and Ruppel, 1957), the formation is about 45 feet thick and consists of 35 feet of yellow to gray chert overlain by 10 feet of yellowish-brown very fine to medium-grained quartzite. Phosphatic fragments and chips occur in the quartzite.

\section{JURASSIC ROCKS}

The marine Jurassic rocks of west-central and southwestern Montana were originally described by Peale $(1896$, p. 2), who named them the Ellis formation for exposures near Fort Ellis, Mont. The name was later assigned by Weed (1900) to marine Jurassic rocks in the Little Belt Mountains. In 1945 Cobban (p. 1262-1303) proposed raising the Ellis to the status of a group and subdividing the group 
into three formations: the Sawtooth, the Rierdon, and the Swift, in ascending order.

The nonmarine Morrison formation overlies the Ellis group and is of Late Jurassic age (Imlay, 1948, pl. 2). The Morrison was named and defined by Eldridge $(1896$, p. 60-62) on the basis of exposures along the front of the Rocky Mountains near Morrison, Coln.

Imlay (oral communication) recognized two formations of Late Jurassic age in the Limestone Hills. The lower of these is the Swift formation (Imlay, 1948, pl. 4), of the Ellis group; the upper is the Morrison formation. Because of the thinness of the Swift formation the Jurassic rocks were mapped as one unit.

\section{SWIFT FORMATION}

The Swift formation crops out with the overlying Morrison formation just north of Indian Creek, in a north-south belt 5 miles west of Lone Mountain, and west and southwest of Plunket Lake. It is about 20 feet thick and consists of light-brown to moderate-yellowishbrown friable calcareous sandstone; locally a thin basal conglomerate is present. Local concentrations of pelecypod shells characterize the formation. Although a considerable time elapsed between deposition of the Phosphoria and Swift formations, there is no angular discordance between the formations, and the amount of pre-Jurassic erosion was apparently slight. Greater thicknesses of the Ellis group are present northwest and east of the Townsend Valley, suggesting that this was a high area on the pre-Ellis surface. The isopach map of Schmitt $(1953$, p. 368) clearly shows this thinning of the Ellis group.

\section{MORRISON FORMATION}

The Morrison formation overlies tbe Swift sandstone with apparent conformity. It is about 540 feet thick in the Limestone Hills but appears to be considerably thinner in the southern part of the area. The greater part of the formation consists of varicolored red, olive, and gray shale, mudstone, and siltstone, but some thin beds of limestone and fine-grained sandstone are present. In the upper part of the formation thick lenticular beds of chert-rich "salt-and-pepper" sandstone are common. These sandstones resemble the basal sandstones of the Kootenai formation, making it difficult to place the contact between the Morrison and Kootenai formations.

The Kootenai formation rests on the Morrison formation with apparent conformity in the Townsend Valley. In the Sweetgrass arch in northern Montana, Cobban (1945) found evidence of a period of folding and erosion after deposition of the Morrison and before deposition of the Kootenai. The correlation charts of Cobban and Reeside (1952) indicate a time gap of considerable magnitude. 


\section{CRETACEOUS ROCKS}

The Cretaceous rocks of the Townsend Valley area have been divided into six map units. These are, in ascending order, the Kootenai formation, three units of the Colorado formation, the Slim Sam formation, and the Elkhorn Mountains volcanics.

Kootenie was first proposed as a group name by Sir William Dawson in 1885 for exposures of Jurassic and Cretaceous rocks in the Canadian Rocky Mountains. In 1909 Fischer (p. 28-35) re- stricted the usage in the vicinity of Grent Falls, Mont., applying the name Morrison shale(?) to the lower 130 feet of strata and Kootenai formation to the upper 475 feet. The Kootenai formation of Montana now includes the rocks between the Upper Jurassic Morrison formation and the Cretaceous Colorado formation and its equivalents, the lower part of which is Lower Cretaceous. The lower part of the Kootenai formation is equivalent to the Canadian Kootenay formation, and the upper part of the Kootenai is equivalent to the Lower Blairmore formation of Canada (McLearn and Hume, 1927, p. 241).

The Colorado group was named by F. V. Hayden (1876) to include the marine deposits conformably underlying rocks of the Fox Hills group and conformably overlying the Dakota sandstone. The great amount of later work on the group has resulted in detailed division into formations and members in many areas. Cobban and Reeside (1952) give a reference sequence of the divisions for the western interior of the United States in which Colorado group is restricted to beds of Late Cretaceous age below the Telegraph Creek formation. The Mowry shale has recently been assigned an Early Cretaceous age (Cobban and Reeside, 1951) and accordingly only formations younger than the Mowry shale and older than the Telegraph Creek formation should properly be considered as part of the Colorado group. In western Montana, however, it has been customary to consider as Colorado formation all the beds characterized by black shale that overlie the Kootenai formation and underlie the Telegraph Creek formation; this usage is followed in this report.

The names Elkhorn Mountains volcanics and Slim Sam formation have been proposed recently (Klepper, Weeks, and Ruppel, 1957) for a thick unit of predominantly andesitic volcanic rocks that are probably wholly of Late Cretaceous age and for a transition unit lying between the Colorado formation and the volcanics. The type localities of both formations are in the southern Elkhorn Mountains, west of the Townsend Valley. 


\section{KOOTENAY FORMATION}

The Kootenai formation crops out in a narrow belt 4 miles west of Lone Mountain, southwest of Plunket Lake, and along the western edge of the map area north of Indian Creek. In the Limestone Hills just west of the mapped area the formation is 530 feet thick. Southwest of Lone Mountain, the formation was eroded away before the Elkhorn Mountains volcanics accumulated (pl. 42). A three-fold division of the formation is recognizable. The lower part, typically about 50 feet thick, consists of fine- to coarse-grained locally conglomeratic salt-and-pepper sandstone that shows scouring and crossbedding, and subordinate interbedded greenish-gray and grayishred silty claystone and siltstone. The middle part of the formation is 350 to 400 feet thick and consists of varicolored (mostly olivegray to greenish-gray with smaller amounts of grayish-red to grayishpurple) calcareous siltstone, silty claystone, and shale with common irregular concretions of impure limestone. The upper part of the formation comprises 20 to 35 feet of dark-gray fossiliferous freshwater limestone beds weathering to light gray, interbedded with claystone similar to that in the middle part of the formation. The uppermost limestone bed is generally overlain by a few feet to 40 feet of gray to olive partly calcareous blocky siltstone and shale.

\section{COLORADO FORMATION}

The Colorado formation exposed in the foothills on the west side of the Townsend Valley consists of about 1,500 feet of interbedded marine and nonmarine black shale, siliceous mudstone, siltstone, and sandstone. For mapping purposes it has been divided into three units: a lower black shale unit, a middle siliceous unit, and an upper black shale unit (Klepper, Weeks, and Ruppel, 1957). The lower black shale unit, in which fossils of Skull Creek age have been found, is believed to contain rocks of the same age as the Fall River sandstone, Skull Creek shale, and Newcastle sandstone of the reference sequence for the western interior (Cobban and Reeside, 1952). The middle siliceous unit probably contains rocks of Mowry to early Niobrara age. Fossils of Mowry, early Carlile, and early Niobrara age have been found, and as no evidence of important depositional breaks was recognized, rocks of Belle Fourche and Greenhorn age may also be present. The upper black shale unit, entirely of Niobrara age, is conformably and gradationally overlain by the Slim Sam formation.

During the summer of 1950 , J. B. Reeside, Jr., and W. A. Cobban spent 3 days examining and collecting fossils from the Colorado group in the Elkhorn Mountains area. Their opinions concerning the correlation of these rocks are summarized by Cobban, May 31, 1951 in 
the following chart: Essentially the same correlation is shown in correlation chart 10b prepared by the National Research Council Committee on Stratigraphy (Cobban and Reeside, 1952).

\begin{tabular}{|c|c|c|c|c|}
\hline $\begin{array}{c}\text { European } \\
\text { equivalents }\end{array}$ & \multicolumn{2}{|r|}{$\begin{array}{l}\text { Composite Great } \\
\text { Plains section }\end{array}$} & \multirow{2}{*}{\multicolumn{2}{|c|}{$\begin{array}{l}\text { Elkhorn Mountains : } \\
\text { (Age of top is unknown) } \\
\text { Slim Sam formation }\end{array}$}} \\
\hline Santonian & \multicolumn{2}{|c|}{$\underset{\text { mation }}{\text { Telegraph Creek for- }}$} & & \\
\hline \multirow{2}{*}{ Coniacian } & \multirow{2}{*}{ 吾 } & \multirow{2}{*}{$\begin{array}{l}\text { Smoky Hill chalk } \\
\text { member } \\
\text { Fort Hays lime- } \\
\text { stone member }\end{array}$} & \multirow{9}{*}{ 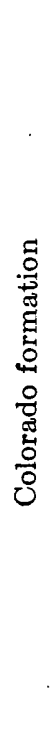 } & Upper black shale unit \\
\hline & & & & \multirow{5}{*}{$\begin{array}{l}\text { Middle siliceous unit } \\
\text { (No faunal or lithologic } \\
\text { correlatives of the } \\
\text { Greenhorn and Belle } \\
\text { Fourche have been } \\
\text { recognized.) }\end{array}$} \\
\hline \multirow{2}{*}{ Turonian } & \multicolumn{2}{|c|}{ Carlile shale } & & \\
\hline & \multicolumn{2}{|c|}{ Greenhorn limestone } & & \\
\hline Cenomanian & Bell & e Fourche shale & & \\
\hline \multirow{4}{*}{ Albian } & & Mowry shale & & \\
\hline & \multicolumn{2}{|c|}{ Newcastle sandstone } & & \multirow{3}{*}{ Lower black shale unit } \\
\hline & \multicolumn{2}{|c|}{ Skull Creek shale } & & \\
\hline & \multicolumn{2}{|c|}{ Fall River sandstone } & & \\
\hline
\end{tabular}

LOWER BLACK SHALE UNIT

The lower black shale unit crops out near the western edge of the map area north of Indian Creek and about $4 \frac{11}{2}$ miles west of Lone Mountain. Its thickness has not been measured in the area mapped, but sections measured nearby indicate a thickness of about 325 feet. West of Lone Mountain the unit was removed by erosion before deposition of the Elkhorn Mountains volcanics.

The lower black shale unit consists of a basal very fine to mediumgrained very pale orange to yellowish-gray orthoguartzite that ranges from 10 to 30 feet in thickness. Bedding planes are irregular and closely spaced (the thicker beds are not more than 4 feet thick) and the beds are commonly laminated and in part cross-laminated. Overlying the basal quartzite is about 140 feet of fissile dark-gray silty shale with a few thin interbeds of olive and gray siltstone. Irregularly and spheroidally shaped rusty weathering calcareous concretions as much as 18 inches in diameter are locally present. The upper 160 feet of the 
lower black shale unit consists principally of dark-gray argillaceous very fine to fine-grained sandstone with some interbedded siltstone and shale.

On the basis of lithology and stratigraphic position the basal quartzite is a correlative of the Fall River sandstone, the middle fissile shale is a correlative of part of the Skull Creek shale, and the upper dark sandstone is a correlative of part of the Skull Creek shale and the Newcastle sandstone (W. A. Cobban, written communication). Fossils of Skull Creek age were collected from the fissile shale and from the lower part of the dark-gray sandstone.

\section{MIDDIE SIICEOUS UNIT}

The middle siliceous unit of the Colorado formation crops out north of Indian Creek near the western edge of the map area and 4 miles west of Lone Mountain. Its thickness is about 900 feet where measured about a mile north of the mapped area west of Lone Mountain. To the south it was removed by erosion before deposition of the Elk: horn Mountains volcanics.

The middle siliceous unit in this area consists of a lower part about 400 feet thick of siltstone and sandstone, a middle part about 275 feet thick characterized by. siliceous mudstones, and an upper part about 225 feet thick dominantly of sandstone. Except for a clean flaggy light-gray fine-grained sandstone at the base, the lower part of the unit consists of argillaceous olive and gray thin-bedded siltstone and sandstone composed of quartz, chert, and sparse feldspar grains set in a matrix of clay minerals and chlorite. The middle part of the unit consists of olive and dark- to light-gray siliceous mudstone interbedded with olive to gray siltstone and minor sandstone. Similar mudstone from the Mowry formation near the Black Hills was studied by Rubey (1929) who concluded that the large amount of silica was provided by the decomposition of included volcanic material by the action of sea water. The upper part of the unit consists of light-gray medium-grained conglomeratic salt-and-pepper sandstone, olive-gray very fine to fine-grained laminated sandstone, and minor amounts of olive to gray siltstone and fissile shale.

\section{UPPER BLACK SHALE ONIT}

The upper black shale unit is present in a single outcrop belt about 4 miles west of Lone Mountain. Half a mile north of this outcrop belt the unit has a measured thickness of 380 feet. Within the map area it is poorly exposed but probably has about the same thickness. South of the diorite porphyry intrusive in secs. 16 and 21 , T. 4 N., R. $1 \mathrm{~W}$. it was eroded away before the Elkhorn Mountains volcanics accumulated (pl. 42). 
The upper black shale unit consists of dark-gray to black fissile shale with some thin beds of very fine grained sandstone and silt-. stone. Spheroidal brown-weathering limy concretions, generally between 8 and 12 inches in diameter, are relatively abundant; thin lenses of coarse feldspar crystals are present locally in the uppermost part.

\section{SLIM SAM FORMATION}

The Slim Sam formation crops out about 4 miles west of Lone Mountain. It is 1,180 feet thick in a measured section 1 mile north of the map area, about 600 feet thick at the north end of the outcrop belt, and absent a few miles farther south. This southward thinning and disappearance is the result of erosion prior to the accumulation of the Elkhorn Mountains volcanics. The formation consists of thinbedded water-laid very fine grained to coarse-grained sandy crystallithic tuff with common thin interbeds of black shale. Toward the top of the formation the beds are thicker and less distinct, the tuff is coarser and contains fewer grains of nonvolcanic origin, and black shale beds are absent.

The black shale beds in the lower part of the Slim Sam formation indicate that the conditions existing when the upper black shale unit of the Colorado formation was deposited were not immediately altered by the abundant supply of volcanic material. In the type area of the Slim Sam formation (Klepper, Weeks, and Ruppel, 1957; Freeman, 1954, p. 21-23) the water-laid tuffs grade upward into the subaerial tuffs and breccias of the Elkhorn Mountains volcanics, but in the area of this report the rocks were tilted and eroded between the deposition of the Slim Sam formation and the Elkhorn Mountains volcanics. From north to south in the area west of Lone Mountain the volcanics rest on progressively older rocks until, at the southernmost exposure of the contact, the volcanics rest on rocks of the Morrison formation. Southwest of Plunket Lake the contact is not exposed, but the volcanics rest upon either the uppermost beds of the Kootenai formation or the basal beds of the Colorado formation.

\section{ELKHORN MOUNTAINS VOLCANICS}

The Elkhorn Mountains volcanics crop out on Lone Mountain and west and south of Lone Mountain, extending in discontinuous exposures to the southwest corner of the area mapped.

The Elkhorn Mountains volcanics in this area consist of gray to greenish-gray breccia, tuff-breccia, tuff, and a few thin flow units, all of andesitic composition. These volcanic rocks were originally coextensive with and are generally similar to those in the neighboring southern Elkhorn Mountains which have been described in more detail by Klepper, Weeks, and Ruppel, 1957. Much of the breccia 
and tuff-breccia is thought to be of volcanic mudflow origin. One thin unit of very thin bedded apparently. water-laid tuff was noted, but in general bedding is difficult to distinguish. The thickness of the formation in the Townsend Valley is estimated to be at least 3,000 feet and may be as much as 6,000 feet.

\section{TERTIARY ROCKS}

The oldest Tertiary rocks exposed in the Townsend Valley are lower Oligocene sedimentary tuffs ${ }^{1}$ that rest with strong unconformity on Late Cretaceous intrusives and older rocks. Oligocene and overlying Miocene or Pliocene rocks of the Townsend Valley are weakly indurated sedimentary tuffs that appear to have been deposited in a gradually subsiding basin in lacustrine and fluviatile environments. A thin unit comprising pediment gravels and local fans deposited on the beveled surface of the Oligocene, Miocene or Pliocene, and older rocks, probably during the Pliocene, is the youngest of the formations of Tertiary age.

The sedimentary tuffs have been subdivided for mapping into 2 units of Oligocene age ( $\mathrm{To}$ and $\mathrm{Tu}_{2}$ ), 1 unit of probable Oligocene age $\left(\mathrm{Tu}_{3}\right), 1$ unit of Miocene or Pliocene age (Tp), and 1 undifferentiated unit (Tun) whose position within the Tertiary sequence is uncertain. The units are similar to and at least in part coextensive with the Bozeman "lake beds" that were mapped in the vicinity of Three. Forks by A. C. Peale in 1893 (pl. 1) but were first described in the Livingston area by Iddings and Weed (1894). W. P. Haynes (1916, p. 287-288) referred the valley sediments of Tertiary age in the Three Forks region, where they are mostly of Miocene age, to the Bozeman formation because they were deposited in subaerial and fluviatile environments rather than in a lacustrine environment. In the Townsend Valley J. T. Pardee (1925) divided the Tertiary lake beds (his usage) into a lower (Oligocene) and upper (Miocene) series for the purpose of description, but on the small-scale map accompanying his report (Pardee, 1925, p. 14) they were shown as one unit. In the Canyon Ferry quadrangle five units of Tertiary rocks have been mapped (Mertie, Fischer, and Hobbs, 1951, pl: 1). The Oligocene rocks in the Townsend Valley appear to the writers to have been deposited mostly in a lacustrine environment, though some units of massive tuff probably accumulated subaerially and some of the gravels are probably stream deposits. The Miocene or Pliocene rocks appear to have been deposited mostly in a fluviatile environment.

1 Sedimentary tuff, as deflned by Wentworth and Williams (1032, p. 50) and used in this report, is a tuff containing a subordinate amount of sediment (nonvolcanic) introduced either during or after deposition. 


\section{OLIGOCENE GEDMMENTARY TUFF}

Three units of Oligocene sedimentary tuff were mapped: a unit of early Oligocene age that crops out south of Crow Creek (unit To on pl.. 42), a unit of Oligocene age that crops out at the northern edge of the area on the west side of the Missouri River (unit $\mathrm{Tu}_{2}$ on pl. 42) and is thought to be a correlative of the unit south of Crow Creek, and a unit of probable Oligocene age that crops out at the north edge of the area just east of the Missouri River (unit $\mathrm{Tu}_{3}$ on pl. 42). The units at the north edge of the area on the west and east sides of the Missouri River are continuations of parts of Tertiary units 2 and 3, mapped in the Canyon Ferry quadrangle (Mertie, Fischer, and Hobbs, 1951, pl. 1).

Though the Oligocene sedimentary tuff south of Crow Creek was mapped as a unit, it can be divided into a rhyolitic part and a bentonitic part for the purpose of description. The rhyolitic part is a sedimentary tuff consisting of generally slightly calcareous poorly indurated ash that contains grains of quartz and rock fragments of nonvolcanic sedimentary origin. The content of volcanic material ranges in individual beds from nearly 0 to 100 percent. Most beds are yellowish gray to pale yellowish brown; a few are white, grayish red, and dark brown. The beds that consist mostly of volcanic material are composed largely of poorly sorted ash fragments ranging from clay size to fine-sand size and subordinately of coarser sand grains and granules. Beds with little volcanic material are very fine to coarse-grained conglomeratic sandstone containing pebbles and cobbles of older rocks as large as 1 foot in diameter. The finer grained beds contain scattered nodules of chert and of radiating calcite; calcareous concretions, some of which formed around bone fragments, are locally common. The bedding in the rhyolitic sedimentary tuff is thin to very thick and indistinct. A few of the beds are lenses only a few tens of feet in length. The unit ranges in thickness from a featheredge where it overlaps the older rocks to possibly 1,000 feet.

Microscopically, the fine-grained sedimentary tuff is composed of shards of volcanic glass with a refractive index between 1.50 and 1.51, grains of quartz, plagioclase, iron oxides, and rarely hornblende, and rock fragments in a matrix of unidentified clayey material generally with a calcite cement. The glass shards show no sign of rounding or of sorting that would be expected if the beds were of fluviatile origin. It is believed that the Oligocene sedimentary tuff is dominantly of lacustrine origin. The volcanic material appears to have been largely carried to the site of deposition by wind, whereas the nonvolcanic material was carried to the lake by streams.

The bentonitic part of the Oligocene sedimentary tuff is a lens, about $2 \frac{1}{2}$ miles long and a few hundred feet thick, in the rhyolitic 
sedimentary tuff. It crops out in an area of about 5 square miles about midway between Lone Mountain and Wheatland School. This lens of bentonitic material is characterized by thick units of grayishgreen and light-brown swelling clays and thinner units of white intraformational conglomerate. Fine- to coarse-grained sand beds and a bed of rounded gravel with a green clay matrix also occur within the lens. The swelling clays are soft, easily eroded, and form rounded. outcrops. They have a cracked surface due to swelling when wetted and subsequent shrinkage when dried. The swelling clays contain scattered grains of silt and fine sand. Because of the swelling, bedding cannot be seen within the clay units. The intraformational conglomerates consist of a white sandy clay matrix and abundant pebbles composed of apparently the same material. A few pebbles derived from the Elkhorn Mountains volcanics and older rocks are also present. The intraformational conglomerate units show crossbedding of a scour-and-fill type.

Vertebrate fossils collected from both the rbyolitic and bentonitic parts of the Oligocene sedimentary tuff at several localities were studied by M. Jean Hough, who made the following identifications and age assignments:

1. Two small areas of fairly abundant bone scrap and separated teeth in the $S 1 / 2$ sec. 25 , T. 4 N., R. 1 W.; bentonitic part of Oligocene sedimentary tuff.

\section{Leptomeryx $\mathrm{sp.}$}

Archaieotherium sp.

Rhinocerotid

Titanothere

Age: Early Oligocene.

2. Fairly abundant bone scrap, including several broken jaws, found along a gully in the NE1/4 sec. 19 and SE1/4 sec. 18, T. 3 N., R. 1 E.; rhyolitic part of Oligocene sedimentary tuff.

Leptomeryx sp.

Hyaenodon mustelinus Scott

Ardynomys occidentalis Burke

Colodon sp

cf. Sespemys sp.

cf. Cedromus sp.

Age: Oligocene.

3. A small area of sparse bone fragments, including broken jaws, in the $S W 1 / 4$ sec. 8 , T. 4 N., R. 1 E.; rhyolitic part of Oligocene sedimentary tuff.

Leptotragulus profectus Matthew

Age: Early Oligocene.

4. A small area of fairly abundant bone fragments and separated teeth in the NW3/4 sec. 20 , T. 4 N., R. 1 W.; rhyolitic part of Oligocene sedimentary tuff; the locality is about one-half mile west of the area mapped.

Ischyromys troxelli Wood

Cylindrodon cf. fontis Douglas

Leptomeryx ? esculcatus Cope 。

$446240-58-3$ 
Age: Early Oligocene.

5. A small area of fairly abundant bone fragments, including broken jaws, in the NW1/4 sec. 1 , T. 4 N., R. 1 W.; rhyolitic part of Oligocene sedimentary tuff; the locality is about 1 mile north of the area mapped.

Titanotheriomys of. veterior Matthew

Megalagus cf. brachyodon Matthew

Brontotherium sp.

Hyracodon sp.

Age: Early Oligocene.

These collections indicate that all of the Oligocene sedimentary tuff south of Crow Creek, except possibly the uppermost beds, is early Oligocene in age and that the bentonitic part is interbedded with the rhyolitic part as indicated by field evidence based on poor exposures

Tertiary unit 2 (pl. 42 , Unit $\mathrm{Tu}_{2}$ ) crops out west of the Missouri River at the northern end of the area mapped (pls. 45, 46). In the Canyon Ferry quadrangle it is about 1,960 feet thick (Mertie, Fischer, and Hobbs, 1951, p. 35), but in the northern part of the map area the exposed thickness is somewhat less. The unit consists of greenishgray bentonitic clay, silty nonbentonitic clay, silt, white very fine to coarse-grained sand, gravel and a few thin beds of carbonaceous shale and impure lignite. Most of the beds are composed chiefly of volcanic material with glass shards and fresh biotite visible with a hand lens. The swelling clays predominate and give rise to a badland topography. The silt, sand, and gravel beds are usually thin and weather as slight ledges in the clay slopes. Most of the sand and gravel beds are argillaceous but a few are clean and well sorted. Most grains are derived from the Elkhorn Mountains volcanics or older rocks, but fragments to the size of small pebbles have been derived from part of the sedimentary tuff sequence. Many of the litbologic types present resemble those in the bentonitic lens in the Oligocer e sedimentary tuff south of Crow Creek and probably formed in a similar environment at about the same time. Plant remains collected from these beds were identified as Oligocene by Roland Brown.

Tertiary unit 3 crops out in a small area immediately east of the Missouri River adjacent to the northern edge of the area mapped. It is about 110 feet thick and corresponds to the basal part of Tertiary unit 3 in the Canyon Ferry Quadrangle (Mertie, Fischer, and Hobbs, 1951): The material exposed consists of slightly indurated, indistinctly bedded, very pale yellowish brown tuffaceous clay and silt with sporadic pebbles as large as 4 inches in diameter. The unit is probably lacustrine in origin, but definite evidence is not available.

Recent alluvium in the Missouri River valley blankets the contacts between Tertiary units 2 and 3, but presumably they are conformable. 
Miocene or Pliocene tuff overlies Tertiary unit 3 with an erosional unconformity (pl. 42). No fossils were found in the unit but it is probably of Oligocene age because the lithology appears to have closer affinity with the underlying rather than the overlying unit. Mertie, Fischer, and Hobbs (1951, p. 31) considered Tertiary unit 3 to be of Oligocene age but included in the unit a large thickness of beds that were mapped by the present writers as of Miocene or Pliocene age. H. M. Sperry (oral communication) has collected fossils of Miocene age from Dry Hollow, about a mile north of the area of this report, within the area shown as Tertiary unit 3 by Mertie, Fischer, and Hobbs.

\section{MIOCENE OR PLIOCENE SEDMMENTARY TUFF}

Sedimentary tuff of late Miocene or early Pliocene age (Tp) covers an area of about 4 square miles east of the Missouri River in the northern part of the area mapped (pl. 42). Several river terraces have been cut into this unit and it is largely covered by terrace sand and gravel. Because of the poor exposure, the stratigraphy of the unit is incompletely known.

The sedimentary tuff rests with erosional unconformity on Tertiary unit 3. It consists of a basal gravel, about 30 feet thick, overlain by 50 to 100 feet of alternating gravel and argillaceous sandstone, which . in turn is overlain by more than 50 feet of similar sandstone without gravel beds. These beds dip gently eastward and apparently are the basal part of a relatively thick conformable sequence of sedimentary tuff that crops out in the vicinity of Duck Creek and Confederate Gulch in the northeastern corner of the mapped area and farther to the east. Fossil teeth collected from this sequence of sedimentary tuff in the NW $1 / 4$ sec. 31, T. 9 N., R. 2 E., were identified by M. Jean Hough as from an advanced Merychippus, subgenus Protohippus, or an early form of Pliohippus, indicating a late Miocene to early Pliocene age.

The tuffaceous sediments of the Miocene or Pliocene sedimentary tuff unit are dominantly light yellowish gray, but locally are light brown. The sandstones are very fine to coarse grained and are cemented by calcite or clay minerals. The gravels consist of subrounded to rounded cobbles and boulders as large as 2 feet in diameter of finegrained andesitic volcanic rocks, siliceous sedimentary rocks, and sparse granitic rocks in a slightly cemented matrix of argillaceous sand. The lithology of the gravel suggests that the source area was in the Elkhorn Mountains.

\section{UNDIFFERENTIATED SEDIMENTARY TUFF}

South of the outcrop belt of Tertiary unit 2 in the northern part of the area sedimentary tuff of uncertain age has been mapped as 
undifferentiated sedimentary tuff (Tun on pl. 42). Rocks of this unit are well exposed in bluffs along the margin of the Missouri River valley, but west of these bluffs they are concealed beneath an unknown thickness of fan gravel and mantle. It is not clear whether the undifferentiated tuff is mainly a southward continuation of Tertiary unit 2 or mainly a younger unit, perhaps a correlative of the Miocene or Pliocene sedimentary tuff, resting with erosional unconformity on Tertiary unit 2. The writers favor the latter possibility.

Exposed beds of the undifferentiated sedimentary tuff consist dominantly of light-grayish-yellow to pale-yellowish-brown poorly sorted sedimentary tuff of clay size to coarse-sand size. Very light gray vitric tuff beds probably represent ash falls. The refractive index of the glass in this unit is 1.50-1.51, which indicates the same composition as the glass in the rhyolitic portion of the Oligocene sedimentary tuff.

\section{TERTIARY AND QUATERNARY SEDIMENTS}

\section{PEDTMENT AND FAN GRAVELS}

The map unit of pediment and fan gravels (QTf on map) includes: a veneer of gravel that was probably deposited at the end of the period of pediment cutting and younger fan gravels that partly bury the pediment. The pediment veneer rarely exceeds 10 feet in thickness. The fan gravels are generally much thicker and in places may be more than 100 feet thick. Because the two gravels are similar in lithology, it is impractical to map them separately and accordingly they are shown: as a single map unit. The pediment gravels are probably Pliocene in age, and the fan gravels probably range from late Pliocene to Recent in age.

North of the Indian Creek fan, the pediment gravels and the overlying fan gravels are comparatively fine grained and consist entirely of Elkhorn Mountains volcanics and younger intrusive rocks. These gravels were deposited by short intermittent streams 2 to 4 miles long, and fan gravels are still being deposited at the mouths of these streams along the front of the Elkhorn Mountains, just west of the map area.

In a narrow belt along the Missouri River east of the Limestone Hills, a rock terrace was cut by the Missouri River during or subsequent to the cutting of the pediment. This terrace is much dissected and partly covered by fan material and slope wash. At present, this terrace is being undercut and destroyed by the Missouri River.

South of the Limestone Hills a pediment extended from the foot of the higher hills carved in the Elkhorn Mountains volcanics eastward across the Oligocene sedimentary tuff at least as far as the principal meridian. Part of this pediment is buried by the fans of Crow and Warm Springs Creeks (pl. 42, $\mathrm{Qf}_{2}$ ). Elsewhere much of the gravel veneer has been stripped from the pediment by erosion, and most of 
what remains is covered by a thin layer of mantle that thickens to the east.

It is likely that Warm Springs Creek was at about its present position during the time of pediment cutting and gravel deposition. If so, the east-sloping pediment flanking the southern Elkhorn Mountains and the postpediment fan gravels derived from these mountains did not extend east of the present course of the creek. However, it is probable that a west-sloping pediment graded to the same base level was cut across the west flank of the Hossfeldt Hills, in the area now completely covered by mantle. The pediment gravel occurring locally between the bedrock exposures in the Limestone Hills and the fan of Crow Creek consists dominantly of pebbles derived from the Belt series. South of Crow Creek the pediment gravels include 2 lithofacies, 1 consisting mostly of fragments of limestone, quartzite, and volcanic rocks as much as 3 feet in diameter and the other, in an area southwest of Plunket Lake, consisting only of limestone fragments. The pediment gravels in the area southwest of Plunket Lake are not more than 5 feet thick.

\section{FLOOD PLAIN GRAVELS}

Gravels $\left(\mathrm{QT}_{\mathbf{g}}\right.$ on map) south of the Limestone Hills near Riverside School probably are postpediment, pre-Pleistocene flood plain deposits of the Missouri River. The gravel is generally comparatively fine grained, the largest boulders being about 1 foot in diameter, and contains crystalline rocks derived from Precambrian formations in the drainage areas of rivers tributary to the Missouri.

\section{QUATERNARY SEDIMENTS}

Five units of Quaternary age have been mapped. 'The oldest of these units $\left(\mathrm{Qf}_{1}\right.$ on map), is represented by remnants of coarse-textured material, probably glacial outwash but perhaps in part morainal material, in the northern part of the map area. Fans at the mouths of Beaver Creek and Indian Creek and the still-forming coalescent fans of Crow Creek and Warm Springs Creek, all mapped as $\mathrm{Qf}_{2}$, are believed to be of Pleistocene to Recent age. A number of small fans $\left(\mathrm{Qf}_{3}\right)$ along the west bank of the Missouri River north of Townsend are probably Recent in age. Mantle, and alluvium (Qal) that cover large parts of the map area are also mainly of Recent age.

\section{OLDER PLEISTOCENE FAN DEPOSITS}

Remnants of a much dissected once continuous fanlike glacial deposit of coarse-textured material in the northern part of the map area have been mapped as older Pleistocene fan deposits $\left(\mathrm{Qf}_{1}\right)$. A larger remnant of this glacial deposit, containing abundant large and 
relatively angular boulders, forms a conspicuous hill east of the town of Winston, 1 mile west of the area of this report. In the map area the deposit is characterized by subangular boulders of Elkhorn Mountains volcanics, some as large as 5 feet in diameter and all derived from the drainage area of Beaver Creek. The part of the deposit in the map area is probably mainly glacial outwash from Beaver Creek, though it may in part be moraine deposited by a glacier that flowed down the valley of Beaver Creek during the older period of glaciation in the Elkhorn Mountains (Klepper, Weeks, and Ruppel, 1957).

\section{RECENT TO YOUNGER PLeISTOCENE FAN DEPOSITS}

Recent to younger Pleistocene fan deposits $\left(\mathrm{Qf}_{2}\right)$ are present south of Beaver Creek in the north-central part of the map area, in the Indian Creek fan north of the Limestone Hills, and south of the Limestone Hills. The deposits in the northern part of the area are part of a large fan situated at the mouth of Beaver Creek and incised by the present channel of the creek just north of the map area. The fan was formed after the older fanlike deposit of glacial debris $\left(\mathrm{Qf}_{1}\right)$ was partly destroyed by erosion. It consists largely of cobbles of Elkhorn Mountains volcanics in a sandy matrix and is probably an outwash deposit formed during the wastage of the last (second?) valley glacier that advanced down Beaver Creek. Near Winston the surface of this fan is more than 200 feet below the surface of the older Pleistocene fan.

The Indian Creek fan $\left(\mathrm{Qf}_{2}\right)$ occupies a triangular area bounded by the Limestone Hills on the south and is nearly 4 miles wide near the Missouri River on the east. The fan consists largely of boulders, some as large as 5 feet in diameter, of Paleozoic and Mesozoic quartzite, limestone, and volcanic rocks, all of which were derived from the drainage of Indian Creek and some of which were probably transported from the central part of the Elkhorn Mountains, 8 to 10 miles to the west. Several gravel-filled ancient channels of Indian Creek are as much as 40 feet below the pediment surface and the present day Indian Creek is incised 100 to 150 feet into both the pediment and the fan. The relatively slight dissection of the Indian Creek fan indicates that it is of comparatively recent age. The part of the fan south of Indian Creek is more dissected than that north of the creek and probably is older. The large boulders in the fan indicate that the competence of Indian Creek must have been much greater during deposition of the fan than at present. It appears probable that much of the material in the fan was deposited from streams swollen by melt water during the last glacial stage in the Elkhorn Mountains, and that the Indian Creek fan is contemporaneous with 
the younger Beaver Creek fan. If older glacial deposits contemporaneous with the older Pleistocene fan deposits at the mouth of Beaver Creek accumulated at the mouth of Indian Creek, they must have been either destroyed before deposition of the fan or buried by it, for no trace of such deposits was recognized by the writers in the vicinity of Indian Creek.

South of the Limestone Hills the material comprising the stillforming fans of Crow and Warm Springs Creeks also is mapped as Recent to younger Pleistocene fan deposits $\left(\mathrm{Qf}_{2}\right)$. The Crow Creek fan consists of cobbles and boulders as much as 2 feet in diameter mostly derived from the Elkhorn Mountains volcanics and in small part from older Mesozoic and Paleozoic formations. The visible part of the fan of Warm Springs Creek consists of argillaceous silt and sand that is probably a thin covering over coarser material. This covering of fine-grained material is undoubtedly a reflection of the very.small amount of water now carried by Warm Springs Creek and its intermittent tributaries. Crow Creek, during the spring runoff, is capable of moving material of cobble and at times even boulder size. A swampy area on the Warm Springs Creek fan near its junction with the Crow Creek fan may have been formed by more rapid growth of the Crow Creek fan, which blocked normal drainage on the Warm Springs Creek fan.

\section{RECENT FAN DEPOSITS}

A number of small fans that have formed in very Recent time where small streams cut the bank of the Missouri River are mapped as Recent fan deposits $\left(\mathrm{Qf}^{3}\right)$. Where the meanders of the river impinge against the bank, the small fans have been prevented from forming or have been destroyed. The material of the small fans is mostly reworked material from older fan and terrace gravels.

\section{MANTLE}

Mantle is'shown on the geologic map (pl. 42) where it is thick enough and persistent enough to prevent determination of the underlying rock unit. The underlying units are shown beneath the mantle when they can be projected with reasonable accuracy. Material shown as mantle includes silt of probable eolian origin, terrace gravels along the Missouri River, slope wash, and some small areas of alluvium. The silt of probable eolian origin, which in places is more than 6 feet thick, is widespread south of the latitude of Lone Mountain and is locally present in the northern part of the area. It consists of angular well-sorted grains derived largely from the sedimentary tuffs of Tertiary age. Most of the terrace gravels are east of the Missouri River. They consist mainly of iron-stained pebbles and cobbles in a fine-grained matrix but include local lenses of coarse sand. 


\section{ALLUVIUM}

Alluvium is present along the Missouri River and smaller drainages in the area. It is not mapped separately from fan gravels where it forms a part of an active fan, and it is not shown along many streams where it is present in minor amounts. The alluvium of the Missouri River consists of pebbles, small cobbles, and sand in and along active channels. Abandoned channels are filled with fine sand, silt, and clay. Much of the alluvium of the Missouri River is covered by a layer of soil thick enough to conceal its gravelly nature. The alluvium mapped in the southern part of the area consists of sand, pebbles, and cobbles of local derivation. Sand and pebbles dominate except where slope wash supplies coarser material from the older gravel deposits. In many places slope wash appears to enter the stream channels faster than the streams can remove it, and the alluvium is being buried.

\section{INTRUSIVE ROCKS}

The Cretaceous and older layered rocks are cut by many sills and thin dikes, several partly concordant bodies, and at least one stock. Most of the intrusive bodies are in the area west of a.line from Townsend to Wheatland School (pl. 42). The intrusive rocks are of 3 general types and may be of 3 different ages. Diabase, in sills, has. been found only in rocks of the Belt series and may be as old as late Precambrian. Diorite porphyry, including a wide variety of types of which hornblende diorite porpbyry, augite diorite porphyry and hornblende granodiorite porphyry are the most common, forms dikes, sills, and partly concordant bodies. The rocks of this group are considered to be the intrusive equivalent of the Elkhorn Mountains volcanics because the pyroclastic rocks consist almost entirely of fragments of the various types of rock included in this group. Most and perhaps all of the intrusive bodies were folded and faulted with the enclosing rocks and therefore were emplaced before the culmination of folding, perhaps during the early stages of deformation of the area in the middle part of the Upper Cretaceous. A small part of a stock of relatively homogeneous medium-grained monzonite cutting Elkhorn Mountains: volcanics is exposed on the west flank of Lone Mountain. The stock cuts across the folded rocks and was probably emplaced after the culmination of folding in the latter part of the Cretaceous period.

\section{DIABASE}

In the middle part of the Spokane shale in the Limestone Hills are four en echelon sills of diabase (pl. 42, di). The sills are typically 50 to 350 feet thick but are as much as 550 feet thick locally. An irregular sill of diabase also occurs in the Greyson shale in the Hossfeldt Hills. The sills are lenses that taper out toward each end. 
Haynes (1916, p. 290 and figs. 1 and 2) mapped and described an elongate diabase intrusive body in the double horseshoe bend of the Missouri River; about 5 miles east of the Townsend Valley area at the latitude of Lone Mountain. This intrusive body is along a thrustfault contact between Belt rocks and Cretaceous rocks and is considered by Haynes to be ". . . clearly post-overthrusting, and therefore of Tertiary age." The diabase intrusive bodies in the Townsend Valley area, however, are folded and faulted with the enclosing rocks and are thus older than the main episode of folding and the overthrust faulting, and may be as old as Precambrian. The fact that the diabase of Haynes contains biotite whereas the diabase in the Townsend Valley contains little or none also suggests that the two diabases are of different ages.

Typically, the diabase is a fine- to medium-grained dark-gray rock of ophitic or subophitic texture consisting of labradorite, augite, and a black opaque mineral, probably magnetite. In the finer grained rock most of the randomly oriented plagioclase laths are 0.5 to $1 \mathrm{~mm}$ long and in the medium-grained rock most are 2 to $3 \mathrm{~mm}$ long. Typically the diabase consists of about 60 percent labradorite, 40 percent or less augite, partly altered to fibrous green uralite, and a few percent opaque minerals. Of several samples examined microscopically, all contained micropegmatitic and granophyric intergrowths of quartz and turbid orthoclase and one contained at least 5 percent of this type of intergrowth. Apatite is a common accessory mineral.

\section{DIORITE PORPHYRY AND RELATED ROCKS}

The rocks assigned to this group are fine-grained porphyries, dominantly of dioritic composition but ranging on the one hand to granodiorite porphyry and monzonite porphyry and on the other to basalt porphyry and lamprophyre (in the nongenetic, descriptive usage of Knopf, 1936, p. 1748-1749). Though most of the rocks are clearly porphyries, subequigranular fine- to medium-grained varieties occur in some of the larger intrusive bodies. The most abundant variety is hornblende diorite porphyry.

Rocks of this group form sills, dikes, and, in the Cretaceous rocks of the area, moderately large irregular masses, some of which have approximately conformable bases and discordant tops. Moderately large partly concordant, partly discordant bodies are present in the vicinity of the Montana Silver Star mine and to the north.

The diorite porphyries are similar in composition to the Elkborn Mountains volcanics, and identical rocks comprise virtually all the fragments in the pyroclastic rocks. The porphyries almost certainly were emplaced during the period of volcanism, though perhaps during a slightly longer period of time than is represented by the extrusive 
rocks in the area. Most of the rocks belonging to this group, and perhaps all of them, were emplaced before the culmination of folding, probably during the early stages of folding when lateral compression may have counterbalanced the superincumbent load and produced an environment favorable for emplacement of sills by dilation. The large intrusive bodies in the Cretaceous rocks near the Montana Silver Star mine were emplaced at a very high level in the crust and may locally have broken through to the surface, judging from their irregular tops and the abundance of large dislocated blocks of wall rock in them.

Phenocrysts are distinctly oriented in many outcrops of diorite porphyry. This orientation is particularly noticeable where hornblende phenocrysts are common, well formed, and somewhat larger than the plagioclase phenocrysts, but it is also present in rocks in which only the plagioclase laths are well developed. Systematic study of the lineation in these rocks might provide useful clues to their mode of emplacement, but time did not permit such a study.

In the map area most of the intrusive bodies are massive and consist of a single rock type. These probably formed as the result of a single intrusion of magma. Some of the larger bodies immediately north of the area are in part brecciated or consist of several rock types. These appear to have been formed by several surges of magma.

Most of the diorite porphyry and related rocks are gray or greenishgray fine-grained porphyries in which phenocrysts of plagioclase, hornblende, and augite, in varying amounts, proportions, and sizes, are set in a very fine grained groundmass that cannot be resolved by the unaided eye. The finer grained varieties would probably be referred to as andesite porphyry in the usage of some petrologists. The most common rock type is one in which plagioclase and hornblende phenocrysts are present in about equal amounts and are about the same size, 1 to $2 \mathrm{~mm}$ in length. In some rocks, hornblende phenocrysts are as long as $1 \mathrm{~cm}$ and are intergrown in cruciform or stellate aggregates. Rocks in which hornblende is the sole or predominant mafic phenocryst were mapped as hornblende diorite porphyry (pl. $42, \mathrm{hdp}$ ) and those in which augite is the sole or predominant mafic phenocryst were mapped as augite diorite porphyry (pl. 42, adp). Microscopic study showed that some of the lighter colored hornblende rocks and the very few that contain appreciable biotite contain enough quartz and orthoclase in the groundmass to be classified as granodiorite porphyry. Several bodies that are clearly of this type are so mapped (pl. 42, gdp). Others that may be of granodiorite or monzonite composition are included in the diorite porphyry map unit (pl. 42, dp), as are poorly exposed parts of intru- 
sive bodies that may consist of more than one rock type. A few thin dikes and sills, most of them too small to map separately, consist of a fine-grained groundmass of feldspar and mafic minerals with phenocrysts of augite or, less commonly, bornblende. These rocks, here called augite lamprophyre and hornblende lamprophyre, are also included in the diorite porphyry map unit.

Rocks of this group have a variety of microscopic textures, and range from porphyries with very fine-grained groundmasses to mediumgrained subequigranular rocks. The most common varieties consist of well formed phenocrysts of plagioclase and hornblende or augite, or both, in a groundmass that consists of predominant plagioclase, moderately abundant mafic minerals, and subordinate quartz and alkali feldspar. In some of the finer grained rocks the components of the groundmass form a granular aggregate in which individual mineral grains are difficult or impossible to identify. In others, plagioclase forms microlites or ragged laths arranged in a felted to crudely pilotaxitic fabric. Typically the phenocrysts, though variable in size, are distinctly larger than the components of the groundmass, though in some rocks the texture is seriate and phenocrysts grade imperceptibly into groundmass. In most of the rocks the phenocrysts range from about $0.25 \mathrm{~mm}$ to 2 or $3 \mathrm{~mm}$ in length and the components of the groundmass are $0.025 \mathrm{~mm}$ or less in size. In some rocks in which virtually all the phenocrysts are mafic minerals, the phenocrysts are of a rather uniform size and are much larger than the components of the groundmass, so that the rock has a notably hiatal fabric.

In the coarser grained rocks the porphyritic fabric is indistinct or lacking and the texture approximates xenomorphic granular in which somewhat ragged plagioclase laths and euhedral or subhedral augite or hornblende crystals are partly surrounded by finer grained very irregularly shaped grains or aggregates of quartz, alkali feldspar, or both. In general the coarser grained rocks appear to have more alkali feldspar and quartz than the finer grained rocks, but the difference in composition may not be great, because it is difficult to estimate the amount of quartz and alkali feldspar in the finer grained groundmasses. Hornblende is the characteristic mafic mineral in rocks of this type but a few contain biotite; augite is rare or absent.

The thick sill in the Three Forks formation in the Limestone Hills is a good example of a rock having the composition of granodiorite. The rock consists of about 45 percent zoned plagioclase, 20 percent alkali feldspar, 20 percent quartz, and 15 percent hornblende and secondary biotite. Zoned andesine, in part with sodic rims, and less abundant idiomorphic hornblende, both minerals averaging about $1 \mathrm{~mm}$ in length, form a crystal mesh through which is distributed a 
finer grained aggregate of euhedral hornblende and anhedral quartz and alkali feldspar. Secondary biotite, chlorite, and epidote are common: In most samples plagioclase is partly altered to sericite,: hornblende to biotite or chlorite, and a brown opaque "dust" is dispersed throughout alkali feldspar.

The small intrusive body just east of the north end of this sill consists of a rock of about the same composition but with different texture. This body is probably an offshoot from the sill (pl. 42 , sec. $\left.A-A^{\prime}\right)$. Clear euhedral phenocrysts of zoned andesine 1 to $2 \mathrm{~mm}$ in length, some with a thin sodic rim, constitute about 40 percent of the rock, and smaller fresh phenocrysts of hornblende that is pleochroic from deep green to bright green to clear brown, constitute almost 10 percent. The phenocrysts are imbedded in a fine-grained mosaic consisting of about equal parts of quartz and alkali feldspar with a small amount of plagioclase and a trace of hornblende. Magnetite(?), apatite, and sphene are accessory minerals.

At the other extreme are rocks that grade toward basalt in composition. These rocks generally form small dikes or sills. They contain augite or augite and plagioclase (near $A n_{50}$ ) as phenocrysts in a groundmass of less calcic plagioclase laths, fine-grained pyroxene or hornblende, and little or no quartz and alkali feldspar. In some of these more calcic rocks the fabric tends toward pilotaxitic.

Most of the rocks in the diorite porphyry group are somewhat altered and some are rather strongly altered. The alteration products are mainly chlorite, epidote, and sericite formed at the expense of mafic minerals and plagioclase. Most of the alteration is probably due to deuteric processes, but in some rocks sericite was probably formed by hydrothermal processes. Calcite formed by hydrothermal or weathering processes is abundant in a few rocks.

\section{MONZONITE}

Medium-grained monzonite (pl. 42, mo) crops out on the west flank of Lone Mountain and at several places nearby (Freeman, 1954 , pl. 1). These several outcrops are peripheral to a gently east-sloping dissected plain developed on Tertiary deposits. It is inferred that a monzonite pluton, herein referred to as the Lone Mountain stock, probably underlies an area of several square miles between Lone Mountain and the foothills of the Elkhorn Mountains. The Lone Mountain stock clearly cuts rocks several thousand feet above the base of the Elkhorn Mountains volcanics. It also cuts a diorite porphyry pluton that is genetically related to, though intrusive into, the volcanic rocks (Freeman, 1954, pl. 1). The Lone Mountain stock is generally similar to the Keating Gulch stock (Klepper, 1951, pl. 1, p. 81-85) several miles west of Radersburg, which cuts late 
Paleozoic to Cretaceous sedimentary rocks and a diorite porphyry pluton. Both stocks have about the same bulk composition, though the Keating Gulch stock contains a greater variety of petrographic types, perhaps due to marginal assimilation, and both were probably intruded subsequent to the culmination of folding. These stocks were emplaced after the diorite porphyry and after folding. They are probably contemporaneous with rocks of the Boulder batholith, whose eastern margin is about 20 miles to the west

The Lone Mountain stock consists mainly of rather homogeneous medium-grained monzonite that grades toward quartz monzonite locally and that is a porphyry in at least one place near the margin of the stock. The monzonite consists of 40 to 50 percent andesine $\left(\mathrm{An}_{30-40}\right.$ in different specimens), 30 to 40 percent potash feldspar, 2 to 10 percent quartz, 10 to 30 percent mafic minerals, 1 to 3 percent magnetite, and sparse accessory apatite and moderately coarse sphene. In some samples augite is the principal mafic mineral, and pale-green hornblende and brown biotite, both formed in part at the expense of augite and partly altered to chlorite, are subordinate. In others, hornblende predominates, biotite is common, and augite is rare. Typically the rock is a subequigranular aggregate of plagioclase laths, partly rimmed by ragged overgrowths of more sodic plagioclase, and subhedral or euhedral crystals of mafic minerals, ranging from 0.5 to as much as $2.5 \mathrm{~mm}$ in size, in a groundmass of generally smaller subhedral or anhedral grains of potash feldspar and subordinate quartz. One sample at the margin of the stock is monzonite porphyry consisting of about half phenocrysts, 0.5 to $1.5 \mathrm{~mm}$ in length, and half groundmass. The phenocrysts are andesine $\left(\mathrm{An}_{40-45}\right)$, with distinctly more sodic rims that are intergrown with the groundmass, and augite; largely replaced by hornblende. The groundmass consists of a granular intergrowth of orthoclase and subordinate quartz and sodic plagioclase, mostly in grains about $0.1 \mathrm{~mm}$ in size, and irregularly shaped somewhat sievelike biotite flakes up to $0.25 \mathrm{~mm}$ long. This rock may have been formed by emplacement, and rapid cooling against unheated wallrock, of a magma consisting of about half crystals and half liquid, rich in silica, potash, and to a lesser extent, soda.

\section{STRUCTURAL GEOLOGY}

The principal structural features of the area are (1) the broad anticline in the pre-Tertiary rocks of the Limestone Hills; (2) the tightly folded and thrust faulted anticlinorium in the pre-Tertiary rocks of the Hossfeldt Hills; (3) the broad syncline in the pre-Tertiary rocks of the Warm Springs Creek basin, west of the Hossfeldt Hills; and (4) gently folded Tertiary rocks and essentially undeformed late Tertiary and Quaternary deposits that underlie the broad benchlands south of 
Crow Creek and north of the Limestone Hills. The anticlinorium on the west side of the Lombard fault zone in the Hossfeldt Hills may be a continuation of the simpler anticline in the Limestone Hills.

The Precambrian rocks of the area were broadly arched or domed and beveled by erosion prior to Middle Cambrian time. Though a small angular discordance was observed between Precambrian and Cambrian rocks in one part of the area, the dips of rocks on the flanks of the broad dome or arch produced by this deformation are, in general, so gentle that the widespread extent of the arch is evident only because the Flathead quartzite rests on progressively older rocks from north to south across this area and adjacent areas to the north and west (Mertie, Fischer, and Hobbs, 1951, p. 21; Klepper, Weeks, and Ruppel, 1957). The area was again affected by very broad regional doming in post-Permian to pre-Late Jurassic time (Condit, 1918, fig. 14), and perhaps also in post-Cambrian to pre-Late Devonian time, judging from the widespread erosional unconformities that were formed during these intervals. The folds and most of the faults in the pre-Tertiary rocks of the area were formed during a cycle of folding and faulting that commenced locally in the early part of Late Cretaceous time, that may have slightly affected some parts of the area recurrently during the Late Cretaceous, and that culminated in strong folding and thrust faulting before the end of the Cretaceous period. During this folding some of the incompetent limestone and shale units were locally thickened and thinned by plastic deformation.

Relatively large vertical displacements along steep faults since the middle Tertiary have been recognized in nearby areas and probably account for the present form of Bull Mountain (fig. 50) to the west of the map area (Pardee, 1950, p. 401), of the Big Belt Mountains (fig. 50 ) bordering the Townsend Valley on the east (Pardee, 1950, p. 381382 ), and of the northern part of the Elkhorn Mountains to the northwest of the Townsend Valley. Gentle folding and small-scale faulting of Tertiary rocks have been observed in the Townsend Valley (Pardee, 1925 , p. 31-32), and some of the more pronounced topographic features in this area, such as the Limestone Hills, are probably due in part to Tertiary and perhaps to some extent even Quaternary uplift along faults.

\section{PRECAMBRIAN STRUCTURES}

On the west limb of the overturned anticline in the Hossfeldt Hills (pl. $42, \mathrm{SE} / 4$ sec. 7 , T. 3 N., R. 2 E.), the Flathead quartzite clearly truncates beds in the upper part of the Greyson shale at an angle of about $10^{\circ}$ and rests on progressively older beds to the south. Locally on the east limb of the overturned anticline the Flathead rests on progressively older beds to the north indicating pre-Flathead folding 
in the area. This is one of the few reported observations of discordance between late Precambrian and Cambrian rocks in southwestern Montana. In general the Flathead quartzite progressively overlaps older Belt rocks southward from Canyon Ferry to the southern end of the southern Elkhorn Mountains (Klepper, Weeks, and Ruppel, 1957), indicating that the Belt rocks of this area were broadly arched and beveled before the Flathead quartzite was deposited. The scanty available information suggests that the Hossfeldt Hills are not far enough north of the crest of a beveled very broad Precambrian dome or anticline of unknown trend and that one of the gently dipping flanks of this fold extended northward at least as far as Canyon Ferry.

\section{LARAMIDE STRUCTORES}

Two episodes of Late Cretaceous deformation, the latter perhaps continuing into the early part of the Tertiary, are recognized in the Townsend Valley and vicinity. The older episode, heretofore mentioned only briefly (Klepper, Weeks, and Ruppel, 1957), is now rather definitely dated as post-Niobrara and pre-Judith River, for strata as young as late Niobrara (early Late Cretaceous) in age are unconformably overlain by andesitic volcanic rocks. Though these volcanic rocks are unfossiliferous, they were almost certainly continuous with similar rocks on Bull Mountain, 10 to 15 miles to the west (fig. 50), from the basal part of which fossil plants of probable Judith River age have been identified (Roland W. Brown, written communication). To date, the effects of this deformation have been recognized only in a few places in the area between the Missouri River on the east and the Boulder batholith on the west. In the Townsend Valley area this deformation is indicated by rather abrupt truncation of Cretaceous strata in the foothills a few miles west of Lone Mountain. Here andesitic volcanic rocks of probable Judith River age rest on an erosion surface that, within 2 miles along its outcrop, cuts across beds ranging from late Niobrara to Late Jurassic in age and totaling about 2,300 feet in thickness. Though no discordance in dip has been observed on opposite sides of this unconformity, probably due mainly to the poor exposure and the massive character of the volcanic rocks, pre-Judith River deformation is clearly indicated. In the mapped area this deformation produced one or more broad folds with gently dipping flanks;" perhaps locally complicated by faults. Additional evidence of pre-Judith River folding in the vicinity is indicated at the south end of Bull Mountain (about 20 miles west of Wheatland School) where the Elkhorn Mountains volcanics, containing Judith River fossils near the base, overlie Madison limestone with apparent angular unconformity and contain cobbles of Madison limestone in the basal beds (R. A. Weeks, oral communication). That local folding 
at this time may have been rather widespread or that gentle folding or warping may have occurred locally at one or more times during the interval of Late Cretaceous volcanism is suggested by the fact that the Elkhorn Mountains volcanics commonly seem to have a lower average dip than the rocks on which they lie, even though actual discordances can generally not be detected and in many places the volcanics appear to be gradational with the underlying rocks.

The major part of the Laramide deformation occurred in post-Judith River time, after the Elkhorn Mountains volcanics had accumulated; for the volcanics are clearly involved in all the major folds of the area, though locally in adjacent areas they appear to dip less steeply than the underlying rocks, as mentioned above. Of the several major north-trending anticlines and synclines that were formed in postJudith River time east of the present site of the Boulder batholith, only parts of one anticline and one syncline are exposed in the area mapped.

The anticline in the Limestone Hills is a relatively simple fold with a steeply dipping west limb and a rather broad crest. The part of the east limb that is exposed dips gently and is complicated by a few minor wrinkles. The anticline here is cut by a number of steeply dipping northwest-trending faults, along most of which the south block has been displaced relatively to the east. For considerable distances along two of the faults the lateral component of displacement is between 1,000 and 1,500 feet. Most of the faults tend to die out in the Madison limestone and the Greyson shale, but the large fault that crosses the Paleozoic rocks near the middle of the Limestone Hills has been traced westward at least 5 miles beyond the map area with a gradually decreasing offset, and the large fault at the north end of the Limestone Hills is probably continuous with a system of range-front faults in the area north of Indian Creek and west of the mapped area. Similarly, there is evidence in the quadrangle to the west that a significant northwest-trending fault may lie beneath the valley of Crow Creek. Such a fault could explain in part the apparent eastward offset of the anticline between the south end of the Limestone Hills and the Hossfeldt Hills (pl. 42).

In the Hossfeldt Hills, the anticline is more complexly folded and locally overturned and cut by thrust faults. The east limb of the anticline here has ridden eastward along a zone of thrust faulting in the southeastern corner of the map area (pl. 42, secs. B-B' and C- $\mathrm{C}^{\prime}$ ). This zone of thrust faulting, the Lombard overthrust of Haynes (1916), has been shown to extend from near Three Forks to the double horseshoe bend of the Missouri River east of Toston (Haynes, 1916, p. 270273), and, in all probability, it continues northward beneath Tertiary and Quaternary cover to join with the zone of thrust faulting along 
the west flank of the Big Belt Mountains east of Canyon Ferry (Mertie, Fischer, and Hobbs, 1951, pl. 1, p. 51-52). The trace of the Lombard fault zone is markedly convex to the east and, between the Limestone Hills and the Hossfeldt Hills, the axis of the major anticlinal fold is either similarly arcuate to the east (pl. 42) or is displaced along a concealed fault or faults similar to those in the Limestone Hills.

From these observations it is inferred that: (1) the series of major north-trending folds in and west of the area formed in response to lateral forces acting from the west and rather uniformly applied from the north to the south end of the area; and (2) at the culmination of this episode of folding, rocks along an arcuate line from near Three Forks, through the double horseshoe of the Missouri River (11 miles east of Lone Mountain) to Canyon Ferry, were thrust eastward. Judging from the eastward bowing or offsetting of the anticlinal axis in the area between the Hossfeldt Hills and the Limestone Hills, the displacement along the Lombard fault zone may have been greater in this latitude than it was to the north and south. Haynes (1916, p. 271-273) reports that near Lombard (in the double horseshoe bend of the river) Belt rocks are thrust over Jurassic and Cretaceous rocks: and estimates that the displacement on the fault plane is about 2 miles and the stratigraphic displacement about 6,800 feet. The displacement here is along a single fault that dips about $40^{\circ} \mathrm{W}$. In the Hossfeldt Hills the displacement is distributed along several strands: comprising the fault zone. Though it is by no means certain, the suggestion is that the aggregate displacement here is less than that. at Lombard. Northward from the double horseshoe bend to the vicinity of Canyon Ferry the zone of thrust faulting is concealed by Tertiary and Quaternary deposits. Judging from the striking discordance of structures on opposite sides of the fault zone at Canyon Ferry, the displacement there may be as great or greater than at. Lombard.

In the Hossfeldt Hills, rocks in the overriding block within 3 miles. of the outcrop of the Lombard thrust are folded and cut by several subsidiary thrusts along which displacement probably has been. relatively small. In the Limestone Hills, about 8 miles west of the outcrop of the Lombard thrust, the rocks in the overriding block are cut by steeply dipping northwest-trending faults, along each of which. the block to the south was displaced relatively to the east, probably largely by strike slip. This pattern suggests that stresses in theoverriding block near the thrust surface were relieved mainly by folding and minor thrusting, while at a greater distance from the thrust. the relief was by strike-slip movement along faults that may haveformed earlier in the deformation but that acted as tears during the: 
latest stage of the deformation. It is possible, however, that another thrust fault, generally parallel to the Lombard fault, lies beneath Tertiary and Quaternary cover immediately east of the Limestone Hills and that the surface traces of the tear faults are therefore relatively close to an actual surface of thrust displacement. The possibility that such a fault may exist is suggested by the presence of thrusts to the west of the Lombard fault in the Hossfeldt Hills, especially by the thrust fault that passes beneath cover about $1 \frac{1}{2}$ miles southeast of Plunket Lake. That this postulated fault may continue northward toward the Spokane Hills with increasing throw is suggested by the striking discontinuity between the south end of the north-trending syncline in the Spokane Hills (Mertie, Fischer, and Hobbs, 1951, pl. 1), a few miles north of the map area (fig. 50), and the generally east-trending structures in the north end of the Elkhorn Mountains 2 to 8 miles west of these hills (H. W. Smedes, oral communication).

The reason for the apparent eastward displacement or bowing of the major anticline south of the Limestone Hills is not clear, because the critical area is covered by Tertiary and Quaternary deposits. A possible explanation is that a major northwest-trending fault belonging to the prominent set exposed in the Limestone Hills is buried beneath the Crow Creek fan. The valley of Crow Creek is controlled by a fault or fault zone of this trend for at least 10 miles west of the map area. Exposures several miles west of the map area suggest that the block south of this fault moved east and that the displacement is relatively small (R. A. Weeks, oral communication). Judging from the behavior of other faults of this same set in the Limestone Hills, it is possible that the eastward displacement of the south block may be much greater in the area south of the Limestone Hills than it is farther to the west, though probably not great enough to account for the total indicated displacement of the anticline, which is 2 to 4 miles. Another possible explanation is that part and perhaps most of the apparent displacement is due to one or more north-trending thrust faults beneath the fans of Warm Springs and Crow Creeks, such as the postulated fault east of the Limestone Hills. Though an apparent displacement or curvature of this type could also be the result of crossfolding along an east-trending axis, folding of this type has not been recognized elsewhere in the area, and it therefore seems unlikely that it occurred here.

\section{TERTIARY STRUCTURES}

Structures in the Tertiary rocks are difficult to detect because of the poor exposure of these weakly consolidated rocks. Nevertheless, it is rather clear that in the mapped area the Tertiary rocks form a homocline that is broken locally by faults. The observed faults are small and could not be traced due to poor exposure and lack of marker 
beds. Accordingly, they are not shown on the geologic map (pl. 42). The dip of the beds, probably in part due to initial dip, is in general $5^{\circ}$ to $20^{\circ} \mathrm{E}$. Locally the dip is steeper or is to the north or south, probably due to tilting along small faults and to local minor folds. The Tertiary rocks were deposited in a basin that, at least in the northern part of the area mapped, subsided gradually during filling probably due to recurrent movement along concealed step-faults trending north to $\mathrm{N} .30^{\circ} \mathrm{W}$. and belonging to the same system as the range-front faults along the east front of the northern part of the Elkhorn Mountains, 1 to 2 miles west of the northern part of the map area.

After deposition of the Miocene or Pliocene sedimentary tuff the rocks of the Townsend Valley region were tilted east or northeast. Deformation was greatest in the northern part of the area. Here the older beds, along the west side of the basin, dip $20^{\circ}$ to $30^{\circ} \mathrm{E}$ and locally as steeply as $40^{\circ} \mathrm{E}$, whereas the younger beds farther east generally dip only $10^{\circ}$ to $20^{\circ} \mathrm{E}$. The older beds were probably gradually tilted during the period of their deposition as mentioned above. Subsequently the entire prism of Tertiary sediments was tilted gently to the east. A slight angular discordance between Oligocene and Miocene sediments east of the mapped area was recognized by Pardee (1925, p. 30), but within the area of this report, though Miocene beds rest on Oligocene beds with erosional unconformity, no discordance was observed between them.

Several miles east of the area a north-trending anticline in Tertiary rocks has been traced from the latitude of Toston to that of Townsend (Pardee, 1925, p. 31-32; Lorenz and McMurtrey, 1956, pl. 19). The axis of this anticline coincides closely with the probable position of the Lombard thrust fault beneath the Tertiary beds, suggesting that middle Tertiary renewal of movement along the Lombard fault may have been responsible for this gentle folding of the Tertiary rocks. The east limb of the anticline dips somewhat more steeply than the west limb, perhaps on the average $20^{\circ} \mathrm{E}$ to $10^{\circ} \mathrm{W}$, which is compatible with folding due to renewed movement along the fault zone.

Along the west margin of the map area north of Indian Creek, Upper Paleozoic and Mesozoic rocks in a minor syncline on the west flank of the Limestone Hills anticline are cut by a complex network of minor faults. These faults are splits of a range-front fault system along which there has been a relatively large stratigraphic displacement, probably in large part of middle Tertiary or younger age, west of the northern part of the map area. The northernmost fault in the Limestone Hills, probably also is linked, beneath the cover north of Indian Creek, with a fault of the range-front system in the Winston quadrangle and may have been reactivated in late Tertiary or early Quaternary time. 
Pleistocene to Recent faulting is indicated in sec. 2, T. 8 N., R. $1 \mathrm{E}$. where coarse gravel, probably belonging to the older Pleistocene fan deposits, appears to be in fault contact with undifferentiated sedimentary tuff.

\section{GEOLOGIC HISTORY}

The pre-Tertiary geologic history of the southern Elkhorn Mountains has been described recently by Klepper, Weeks, and Ruppel (1957) and as this description applies equally well to the Townsend Valley it is here summarized.

An unknown thickness of fine-grained clastic rocks assigned to the Belt series of Precambrian age was deposited in a shallow sea. These rocks were broadly arched and beveled before the Flathead quartzite was deposited in Middle Cambrian time. Cambrian rocks comprise a conformable sequence of carbonate rocks, shale, and sandstone that was deposited in a marine environment. Marine Devonian rocks rest without angular unconformity on an erosion surface of very slight relief formed on Cambrian rocks and are overlain by an upper Paleozoic marine sequence of carbonate rocks with subordinate sandstone and shale. The Swift formation, a thin Upper Jurassic marine unit, rests without recognizable angular discordance on an erosion surface of very slight relief formed on the Phosphoria formation of Permian age. The Swift formation is conformably overlain by continental deposits of Late Jurassic (Morrison formation) and Early Cretaceous (Kootenai formation) age. The Colorado shale, a sequence of alternating marine and nonmarine shale and sandstone of Early and Late Cretaceous age, conformably overlies the Kootenai and is conformably and gradationally overlain by the Slim Sam formation, a predominantly nonmarine unit mainly of andesitic composition. Locally minor folding and perhaps faulting followed the deposition of the Slim Sam formation. Volcanism in or near the area occurred intermittently throughout the Late Cretaceous. The Elkhorn Mountains volcanics, overlying the Slim Sam formation, is probably mainly of Judith River age, and consists of a sequence of breccias, tuffs, and flows mainly of andesitic composition. Irregular stocks with associated sills and dikes were intruded into the Elkhorn Mountains volcanics and older formations throughout the period of volcanism and prior to the main episode of folding and faulting in very Late Cretaceous time. One stock within the map area was emplaced after the main episode of folding and faulting, perhaps at about the time that the Boulder batholith was emplaced farther west.

The Cenozoic history of southwestern Montana has been described by Atwood (1916) and Pardee (1950). Summaries of their interpretations of the principal geological events are included in the following table: 
GEOLOGY OF PART OF TOWNSEND VALLEY, MONTANA

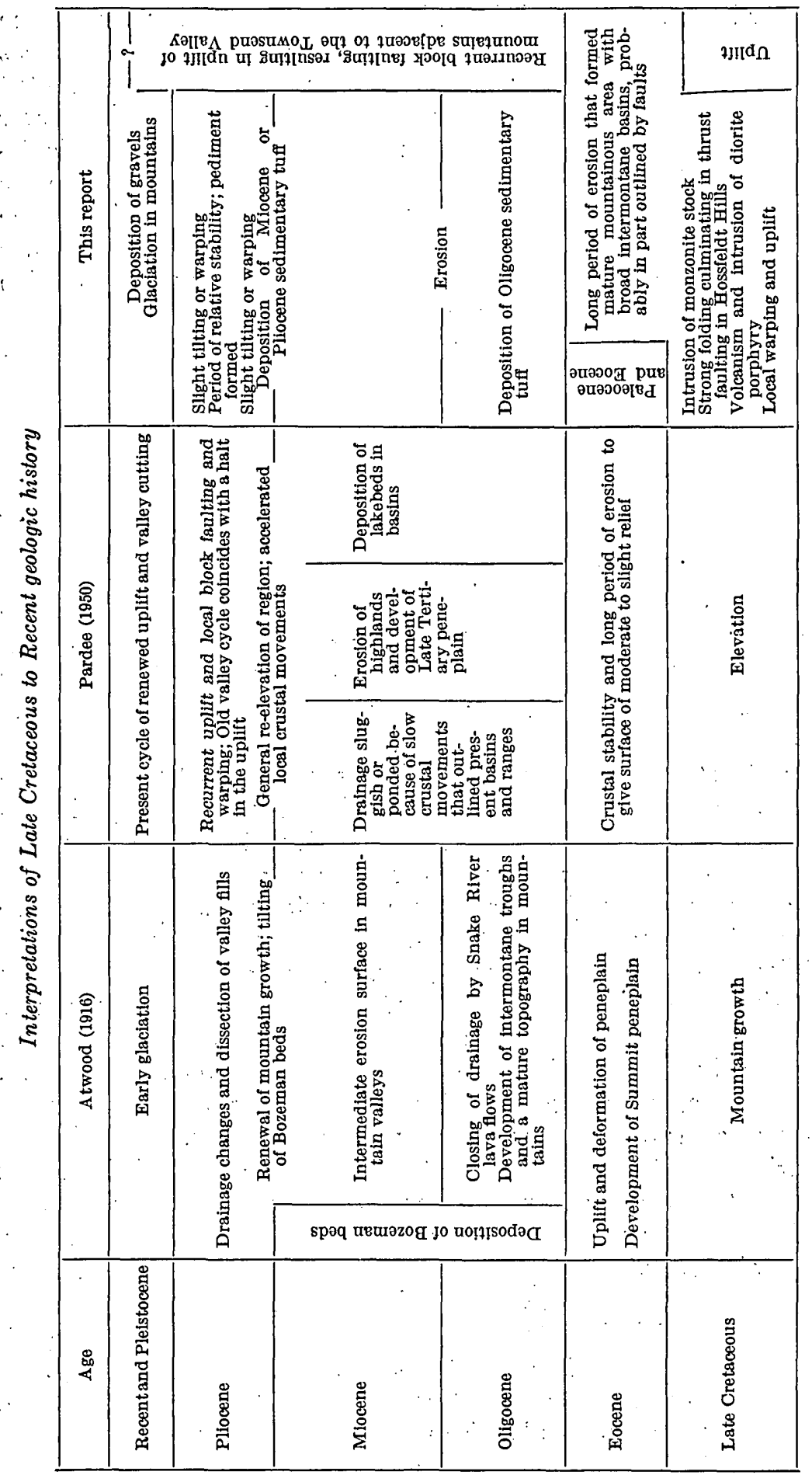


Atwood (1916) expressed the belief that erosion during the Eocene produced a peneplain in western Montana and eastern Idaho that was. uplifted and deformed near the close of the Eocene. He attributed the formation of the intermontane basins in which the so-called lower Bozeman beds and their equivalents were later deposited to this deformation and subsequent erosion, and believed that the basins were further developed by closing of the drainage from this district by the outpouring of lava in the Snake River area to the south. Pardee (1950) considered the Eocene as a stable period during which erosion produced a surface of moderate to slight relief. He believed that slow crustal movements along range-front faults outlined the present. basins and caused the drainage to become sluggish or ponded, and that changes of drainage by lava eruptions were not important.

In the Townsend Valley there are no known deposits of Eocene age and no recognizable physiographic features of that age, though the ancestral Elkhorn Mountains existed to the west, and perhaps highlands existed at the present sites of Lone Mountain, the Limestone Hills, and the Hossfeldt Hills. The formation of the intermontane basins, including the Townsend Valley, and contemporaneous erosion in the adjacent highlands produced a mature topography that was. partly covered by the Oligocene sedimentary tuff. About 2 miles. west of Radersburg the Oligocene beds rest upon a surface that slopes. generally eastward, as steeply as $20^{\circ}$.

The oldest known Tertiary rocks in the Townsend Valley are sedimentary tuffs of early Oligocene age. These rocks were deposited in one or more lakes into which streams of considerable competency built deltas. The greater abundance of fossil remains of land vertebrates. along the present margin of the Oligocene rocks on the west side of the Townsend Valley suggests that it represents part of the shore zone of an Oligocene lake. The highest preserved evidence of a shoreline in the vicinity is now at an elevation of about 4,900 feet along Johnny Gulch about 4 miles west of the mapped area, where undeformed Oligocene beds extend into the foothills of the Elkhorn Mountains. In the area of this report the Oligocene sediments have been eroded to expose older rocks at considerably lower elevations.

During early Oligocene time, as the Townsend Valley subsided or as the mountain areas adjacent to the valley were uplifted, considerable debris, mainly gravel, was washed from the mountains to the basins. The acidic volcanic material that makes up a considerable part of the Tertiary deposits is generally of sand size and finer and was probably transported mainly by wind from the west or northwest and, in part, reworked by streams in and adjacent to the Townsend Valley. A volcanic center probably existed near Winston (Pardee, 1925, p. 41), in an area now covered by late Tertiary or Quaternary gravels, because 
the Tertiary sequence east of Winston is unusually thick and contains some beds of volcanic "conglomerate" of possible mudflow origin (Pardee, 1925, p. 27). The common occurrence of Oligocene sedimentary tuff in other intermontane basins of western Montana indicates that volcanism at that time was widespread.

In the southern part of the area of this report the Oligocene sediments are comparatively thin, suggesting that the basin in which they were deposited was comparatively stable during the period of sedimentation. In the northern part of the area, however, the great thickness of Tertiary unit 2, which according to Pardee (1925, p. 27) is 2,800 feet, indicates that these sediments accumulated in a rapidly subsiding basin. The lower Oligocene sediments occur throughout the Townsend Valley, but upper Oligocene and Miocene beds are known only in the northern and eastern parts, suggesting that subsidence and deposition continued to a later date in these areas, though it is possible that late Oligocene and Miocene sediments were deposited over a broader area and have since been removed by erosion.

Pardee (1925, p. 29) indicates that the Miocene beds east of Townsend are separated from the Oligocene beds by an angular discordance of $4^{\circ}$ to $8^{\circ}$. No discordance was observed at the few places in which Oligocene and Miocene beds are in contact in the map area, but the Oligocene beds in this part of the area commonly dip $20^{\circ}$ to $25^{\circ} \mathrm{E}$ and in one place dip as much as $40^{\circ} \mathrm{E}$, whereas the dip of the Miocene or Pliocene beds is typically less than $20^{\circ}$. These observations suggest that the Oligocene beds may have been slightly tilted before deposition of the Miocene or Pliocene sediments, but they can also be interpreted to be the result of gradual subsidence during the period of deposition, probably due to recurrent movement along faults in the basement rocks beneath the basin, and to subsequent eastward tilting of the Oligocene and the Miocene or Pliocene sediments.

The abundance of gravel in the basal 200-foot-thick zone of the Miocene or Pliocene sedimentary tuff suggests continued or renewed uplift of the mountain areas adjacent to the Townsend Valley. The basal gravels appear to occupy a shallow valley cut into sediments of Tertiary unit 3 (pl. $42, \mathrm{NW} 1 / 4$ sec. 36, T. 9 N., R. 1 E.). Beds above the basal zone closely resemble the rhyolitic parts of the Oligocene sedimentary tuff, and like them are believed to have been deposited in lakes.

The Pliocene epoch in western Montana (Atwood, 1916; Pardee, 1950) was a time of continued mountain growth, probably due to. recurrent uplift along range-front faults, and of restoration of uninterrupted drainage in the intermontane valleys. Pardee (1950) recognized a halt that he termed the Old Valley cycle in the Pliocene uplift of western Montana. At this time many of the larger streams 
cut broad valleys that are still clearly evident: Adjacent to the map area the Old Valley cycle is represented by a high-level terrace (Bench 1 of Pardee; 1925) east of the Hossfeldt Hills near Clarkston and along the east side of the Townsend Valley. During the Old Valley cycle in the map area the nearly constant base level of the Missouri River permitted a pediment to be formed along the east flank of the Elkhorn Mountains. : Conspicuous remnants of this pediment are preserved south of Line Mountain and west of the Missouri River between Indian Creek and Beaver Creek (pls. 45, 46). The pediment, which is now moderately dissected, and Pardee's Bench 1, its correlative along the eastern side of the Townsend Valley, bevel the deformed Oligocene and the Miocene or Pliocene sediments and older rocks. The fact that beds containing fossils of probable early Pliocene age were slightly deformed and subsequently beveled to a pediment suggests that the close of the Old Valley cycle could not have been much before the middle of the Pliocene and may have been as recent as late Pliocene or early Pleistocene.

After the Old Valley cycle the rocks of the Townsend Valley were slightly deformed with resulting slight deformation of the pediment and Pardee's Bench 1 (1925, p. 41-42). Throughout most of the Townsend Valley the pediment and the bench appear to have been uplifted a few hundred feet judging from the elevation of the surfaces above the present streams and the amount of dissection. Perhaps the uplift at the northern end and along the eastern side of the valley was somewhat greater than along the western side. In the area where the toe of the pediment is covered by the Warm Springs fan there has been little or no uplift.

A cursory examination of the Townsend Valley with the broad, low divides at either end might lead to the conjecture that the Missouri River flowed through the divides in relatively recent time. However, the river is deeply incised both east of the Hossfeldt Hills near Clarkston and east of the Spokane Hills indicating that it has followed its present course into and from the Townsend Valley since the Old Valley cycle. Although the Spokane Hills north of the area and the Hossfeldt Hills in the area may have been uplifted during the Pliocene, such uplifts apparently did not materially influence the course of the Missouri River. There is no indication that a large river has occupied the divides west of the Spokane Hills and the Hossfeldt Hills since the deposition of the Tertiary sediments, though one may have prior to the Oligocene.

By the close of the Pliocene epoch the major physiographic features of the Townsend Valley had been formed. In post-Pliocene time some uplift of the Big Belt and northern Elkhorn Mountains is believed to have occurred, probably along range-front fault systems, the 


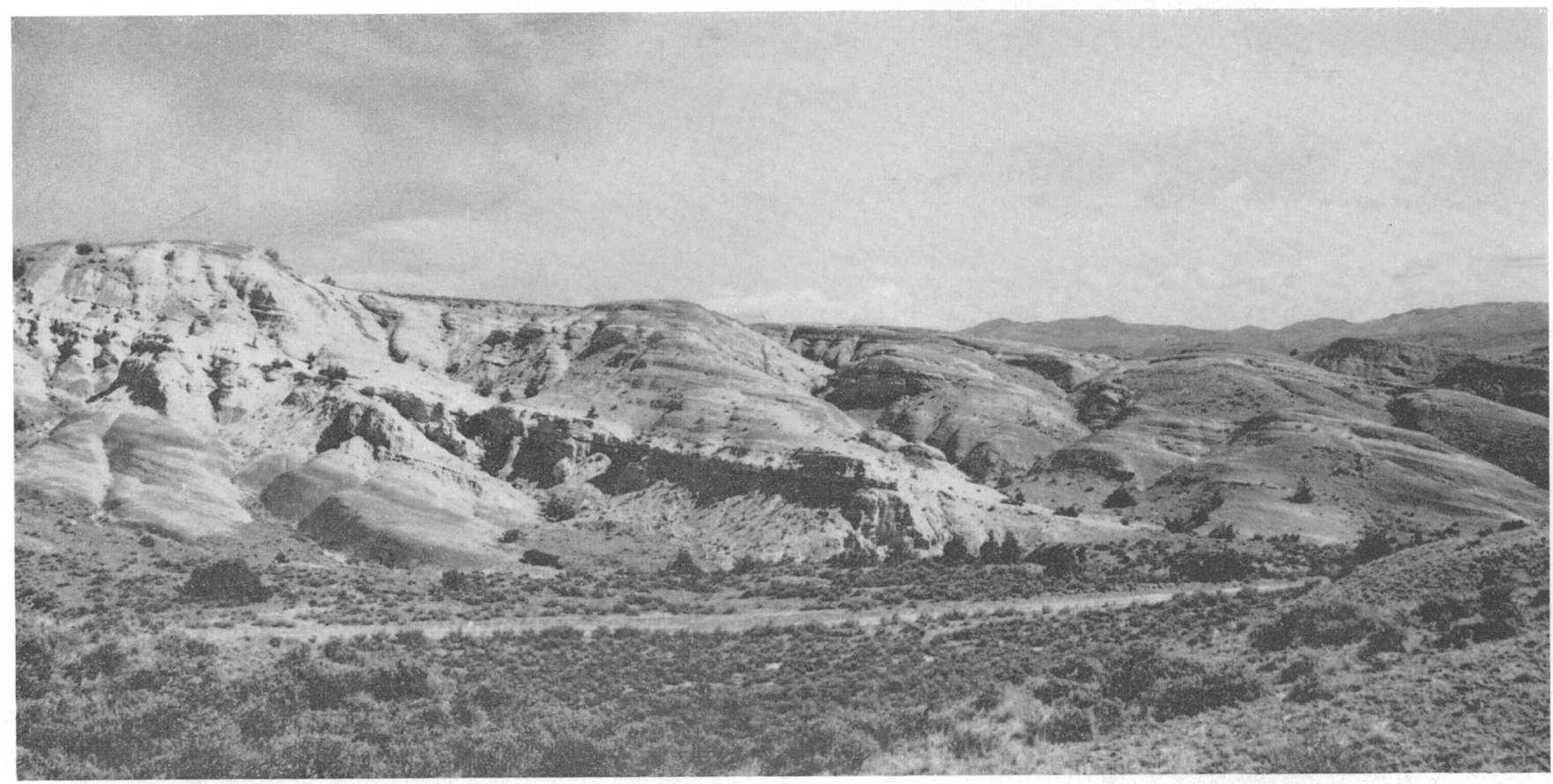

View toward the north-northwest from road indicated along north margin of plate 42, showing lower part of Oligocene sedimentary tuff Tu2 transected by Pliocene(?) pediment. Darker beds are bentonite or bentonitic tuff. 


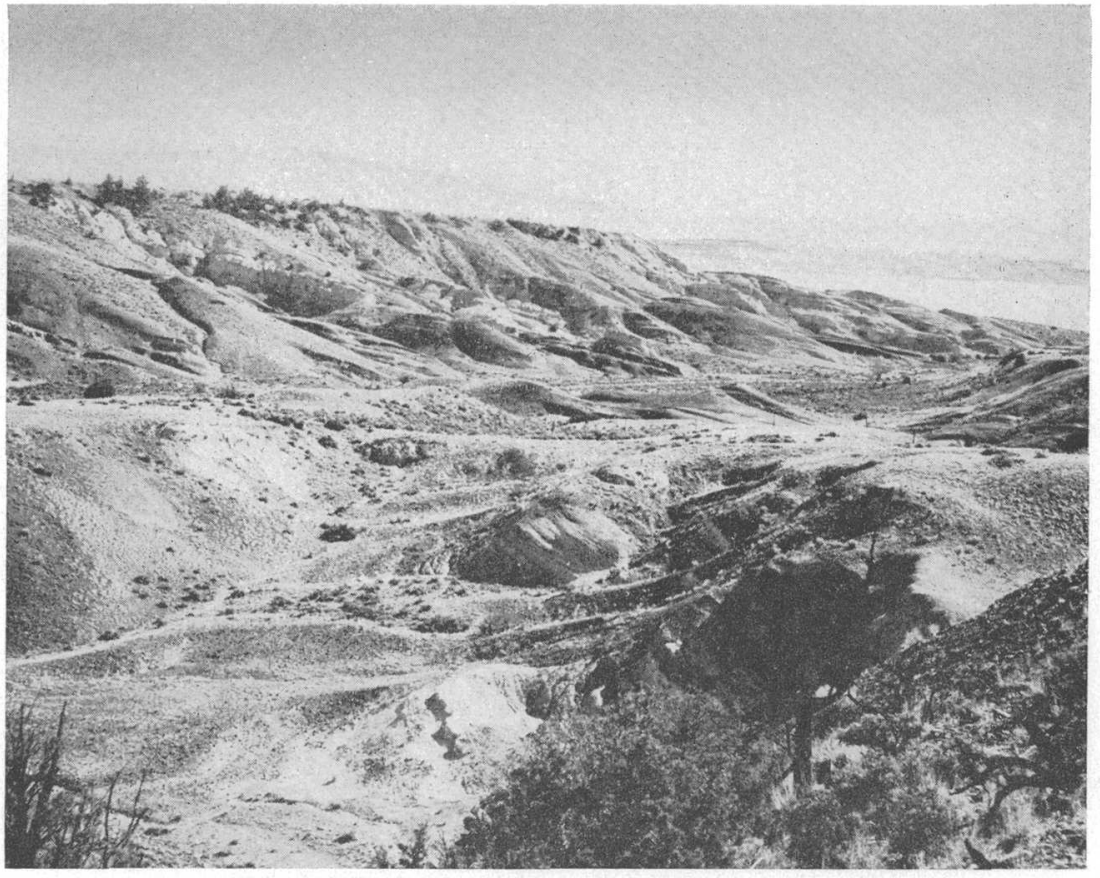

View toward the east-northeast from vicinity of area shown in plate 45, showing upper part of Oligocene sedimentary tuff $\mathrm{Tu}_{2}$ transected by pediment. 
Missouri River downcut a few hundred feet at the north end of the Townsend Valley and developed a complex group of terraces, and a large amount of material was deposited by small streams as fans along the west side of the valley. South of Crow Creek the record of Pleistocene events is fragmentary. The pediment that was formed along the southwest side of the valley during the Old Valley cycle appears to slope beneath the Warm Springs Creek fan, while the Hossfeldt Hills along the southeast side of the valley have been elevated relative to the Missouri River, as shown by the entrenchment of the river.

In the northern part of the map area the physiographic record of post-Pliocene time is more complete. The coarse-textured morainal material or glacial outwash $\left(\mathrm{Qf}_{1}\right)$ at the mouth of Beaver Creek is thought to have been deposited during the earliest period of glaciation in the Elkhorn Mountains (R. A. Weeks, oral communication) when the Missouri River flowed at a higher level. Later, Beaver Creek, as a result of downcutting by the Missouri River, cut through and removed much of this debris and then deposited a fan $\left(\mathrm{Qf}_{2}\right)$ north and south of the principal remnants of the debris, probably during a later period of glaciation. The fan at the mouth of Indian Creek is probably of about the same age. Further downcutting by the Missouri River caused Beaver Creek to become incised into the northern lobe of this fan and to abandon the southern lobe, the surface at the lower end of which is now about 75 feet above the river level.

East of its present course, post-Pliocene downcutting by the Missouri River has left a series of terraces that cannot be correlated accurately with the fan surfaces to the west. On the hill between the Missouri River and Confederate Gulch a total of seven terraces was recognized. The highest terrace, just north of the mapped area, may represent the river level at the time of deposition of the older Pleistocene fan deposits $\left(\mathrm{Qf}_{1}\right)$ at the mouth of Beaver Creek. The lower terraces here and remnants of terraces farther south within the map area probably represent the meandering of the river back and forth across its valley rather than any halt in downcutting. The process. of downcutting as the Missouri River meanders through its valley has continued to the present. Small fans (pl. $1 \cdot \mathrm{Qf}_{3}$ ) have formed at the mouths of small streams except where the river impinges against the terrace.

\section{ECONOMIC GEOLOGY}

\section{METALIIC DEPOSITS}

Though the pre-Tertiary rocks of the area have been rather intensively prospected, few exploitable metalliferous deposits have been found and none were being exploited in 1955. In the past, consider- 
able gold was produced from placers along Indian Creek, and a number of metalliferous lode deposits yielded small tonnages of ore. Most of the lode deposits are in 1 of 3 groups: a small group of goldpyrite veins in the Elkhorn Mountains volcanics about 3 miles west of Lone Mountain (pl. 42, secs. 10, 11, 14, and 15, T. 4 N., R. 1 W.) and a similar deposit in the marginal part of a monzonite stock on the west slope of Lone Mountain (pl. 42, secs. 7 and 8, T. 4 N., R. 1 E.); a group of lead-zinc replacement deposits in Paleozoic carbonate rocks along the western edge of the map area (pl. 42, sec. 17, T. 4 N., R. 1 W.); and small scattered gold, copper, and manganese deposits, mainly in the Limestone Hills. Elsewhere, only a few scattered prospect pits explore weakly pyritized, silicified, or limonitized zones in pre-Tertiary rocks. Uranium deposits were discovered recently in Tertiary rocks immediately north of the mapped area; similar deposits are likely to occur within the map area.

\section{GOLD-PYRITE VENNS WEST OF LONE MOUNTANN}

Several gold-pyrite deposits in the Elkhorn Mountains volcanics have been prospected in secs. $10,11,14$, and 15 , T. 4 N., R. $1 \mathrm{~W}$. (pl. 42) and a small amount of gold ore has been produced from the Gold Butte deposit of the same type in a monzonite stock on the west flank of Lone Mountain (SE1/4, NE 14 , sec. 7, T. 4 N., R. 1 E.). These deposits are the southernmost representatives in a nearly northsouth trending belt of similar deposits that extends north to the Hassel mining district, which is along Indian Creek 2 miles west of the map area, and includes the Diamond Hill, Keating, Ohio-Keating, and Black Friday mines. The deposits, in general, and the Ohio-Keating, specifically, have been described by Corry (1933, p. 19-22).

The veins in this belt, except the Gold Butte, which cuts a postvolcanic monzonite stock, are in andesitic volcanic rocks or diorite porphyry and other intrusives that are genetically related to the volcanic rocks. Most of the veins in this belt trend north to northwest and dip steeply, but several diverge considerably from the general trend. The ore consists of auriferous pyrite, more or less oxidized to limonite and free gold, in a gangue of quartz, altered wallrock, gouge, and, in some veins, minor amounts of calcite. Some veins contain sparse chalcopyrite or bornite, and a few of the larger ones have yielded a little copper as a byproduct. Most of the gold ore was of relatively low grade. Average recovery of gold from the two most productive deposits, calculated from Reed's data (1951, p. 16), was 0.38 and 0.31 ounce per ton of ore. In the period 1901-48 the principal mines in the belt, all of them north of the area mapped, yielded about 230,000 ounces of gold, 64,000 ounces of silver, and 1,100 tons of copper (Reed, 1951, p. 16). 
In the part of this gold belt that is within the map area there are no accessible mines, and only two deposits have been developed by more than a few prospect pits. At the Gold Butte deposit (Reed, 1951 , p. 59), an iron-stained zone associated with several weak subparallel fractures in the marginal part of the Lone Mountain stock has been explored to a depth of 150 feet by a shaft. The mineralized rock contains limonite, auriferous pyrite, and sparse oxidized minerals of copper. This deposit is of particular interest because it is in a monzonite stock, emplaced after the rocks were folded, and thus is not genetically related to the diorite porphyry intrusives that are contemporaneous with the volcanic rocks and which contain or are near most of the gold deposits in this belt. The gold may have been deposited by residual fluids from the magma that formed the Lone Mountain stock and the nearby Keating Gulch stock (Klepper, 1951) in Late Cretaceous time, or it may be younger than these stocks, but it is clearly pre-early Oligocene.

Three miles to the west, mainly in secs. 10 and 11, T. 4 N., R. 1 W. (pl. 42), a number of mineralized zones in the Elkhorn Mountains volcanics have been prospected. The 2 best defined zones strike northwest, dip steeply southwest, are 4 to 5 feet thick, and contain pyrite largely oxidized to limonite. The principal working is an inaccessible shaft in the $\mathrm{SE}_{1} \frac{1}{4} \mathrm{SE} 1 / 4$ sec. 10 . It is unlikely that any of these deposits have yielded significant amounts of gold ore.

If important undiscovered deposits of gold exist in the area, they are most likely beneath the cover of Tertiary rocks west and southwest of Lone Mountain.

\section{LEAD-ZINC REPLACEMENT DEPOSITS}

A number of replacement deposits containing bodies of lead-zinc ore occur in the north-trending belt of upper Paleozoic carbonate rocks west of Lone Mountain and in the continuation of this belt northward beyond the limits of the map area (Klepper, 1951, pl. 1). The deposits consist of irregular replacement masses of cryptocrystalline silica, mainly jaspery, with variable amounts of galena, sphalerite, and pyrite, largely oxidized to cerussite, smithsonite, calamine, anglesite, limonite, manganese oxide, jarosite, wulfenite, pyromorphite, mimetite, vanadinite, and traces of secondary copper minerals. Drusy quartz and calcite are common in oxidized ore. Though the ores are argentiferous, no silver minerals have been recognized. Most of the deposits are localized along the intersection of steep faults of slight displacement and favorable carbonate beds in the Quadrant and Madison formations.

The principal deposit of this type in the area mapped is on the Lode Star unpatented claim, a part of the Montana Silver Star or 
Summit property, which also includes the Rena Silver, Blackhawk, Red Wing, and Elgin patented claims, all in the southeast corner of sec. 17, T. 4 N., R. 1 W. The claims cover a low rounded limestone ridge north of the county road between Radersburg and Boulder. The deposit on the Lode Star claim is an irregular pipelike replacement in beds several hundred feet below the top of the Madison limestone on the flank of a major north-trending dome. The beds in the vicinity of the mine trend rather uniformly north and dip $40^{\circ}$ to $50^{\circ} \mathrm{E}$. Several hundred yards north of the mine, a small plug of fine-grained diorite porphyry cuts the upper part of the Madison limestone and the overlying formations, and several hundred yards east of the mine, a sill-like tongue from this plug is at the base of the Quadrant quartzite.

The ore body is an irregular tubular replacement body of small cross section elongated in the direction of dip of the beds. It has been followed for 600 feet by a shaft inclined $35^{\circ}$ to $55^{\circ} \mathrm{E}$. The ore is confined to a thin group of favorable beds, within which it appears to have been localized by vertical or steeply dipping east- and N. $10^{\circ}$ W.-trending faults of slight or negligible displacement. Though the ore body is generally tubular, it contains irregular offshoots and protuberances along favorable beds and minor faults. The largest and one of the richest parts of the ore body is adjacent to a north-trending vertical fault, extends for about 50 feet along the body, is 3 to 10 feet thick (normal to bedding) and as much as 35 feet in breadth (parallel to bedding). More commonly the dimensions of the cross section of the tubular ore body, or of offshoots from it, are a few feet by 10 to 20 feet.

The ore is thoroughly oxidized and consists largely of cerussite, smithsonite, and calamine in a jaspery gangue. Limonite, manganese oxide, drusy quartz, and calcite are common, and a little aragonite is present locally. A little galena, sphalerite, and pyrite, probably from the bottom of the incline, which is at the water table, were found on the dumps.

During the period of oxidation of the ore, solution caverns were formed in the limestone, generally along joints or small faults. Openings partly or wholly filled with sand and gravel occur as much as 150 feet below the surface and cracks containing calcite stalagmites and stalactites occur almost at the bottom of the mine, 360 feet beneath the surface.

From 1901 to $1948,1,923$ tons of ore marketed from the Montana Silver Star mine yielded 60 ounces of gold, 16,385 ounces silver, 2.3 tons of copper, 205 tons of lead, and 48 tons of zinc (North Star of Reed, 1951, p. 29). The ore came from the shaft and from small stopes adjacent to the shaft. 
On the Blackhawk claim, about 400 yards northeast of the Lode Star shaft, a similar but smaller replacement deposit along bedding has been explored. The replacement is at the base of a bed of limestone breccia that was probably formed by solution and collapse during a Late Mississippian erosion interval (Klepper, Weeks, and Ruppel, 1957), and is underlain by a bed of silicified massive limestone. The ore lens, which is as much as 1 foot thick but averages only a few inches thick, has been explored to a depth of more than 80 feet by an inclined shaft connected with a vertical shaft. The ore is thoroughly oxidized and consists of cryptocrystalline silica, most of which is jaspery, limonite, cerussite, secondary zinc minerals, manganese oxide, and only sparse remnants of galena.

Crusts and small replacement veinlets and pods of psilomelane or a similar manganese mineral occurring with cryptocrystalline silica in Madison limestone are common on the Blackhawk dumps, as float nearby, and on the dumps of several small pits between the Blackhawk and Lode Star workings. These occurrences appear to to be too small and too sporadically distributed to be of commercial importance.

Several replacement deposits similar to and in the vicinity of the ones described above have been superficially explored, and others may be found in the upper part of the Madison limestone and in beds of carbonate rock in the Quadrant formation.

\section{DEPOSITS IN THE LIMESTONE HILLS}

A few small deposits of gold, copper, and manganese, have been found in the Limestone Hills, but none has been of economic importance. The principal prospects are described briefly as follows:

West of the small body of granodiorite porphyry, along the line between secs. 3 and 4, T. 6 N., R. 1 E. (pl. 42), small irregular siliceous pyritic replacement deposits in the lower part of the Pilgrim dolomite have been prospected by means of a number of pits. About 1,000 feet north of this stock a small replacement body contains marcasite and malachite. About 1,500 feet south of the stock, at the mutual corner of secs. $3,4,9$, and 10, T. 6 N., R. 1 E., is a northwest-trending steeply dipping silicified and limonitic veinlike replacement body in the upper dolomite member of the Pilgrim dolomite. Three prospect shafts 50 to 100 feet deep with some appended level workings have been driven into the deposit. A similar replacement body is in the middle part of the Meagher limestone about 800 feet to the southeast and similar very small replacement bodies are in the upper part of the Pilgrim dolomite at several other places in the Limestone Hills. About 1,500 feet west of the stock a sparsely pyritic quartz vein in the thick granodiorite sill has been prospected to a depth of about 
100 feet by 5 inclined shafts. The vein trends N. $30^{\circ}$ E., dips about $45^{\circ} \mathrm{NW}$., and is as much as 10 feet thick. All the deposits mentioned are thought to have been prospected for gold.

Adjacent to the Radersburg-Townsend road, near the line between secs. 27 and 28, T. 6 N., R. 1 E., a quartz vein containing sparse malachite cuts red argillite of the Spokane shale. The vein is $1 \frac{1}{2}$ to 3 feet thick, trends $N .85^{\circ} \mathrm{W}$., is vertical, and has been explored by a shaft about 100 feet deep and by several pits.

At the north end of the Limestone Hills, small concentrations of pyrolusite occur along northwest-trending steeply dipping quartz veins following joints and faults of slight displacement where they intersect limestone or calcareous beds in the Spokane shale. The veins may also contain a little gold, for Corry (1933, p. 19) describes the Shelby vein of the Toney group, which is probably one of these veins, as an example of a gold vein along "jointing-cracks." Most of the occurrences are within a few hundred feet of the diabase sill that bisects the formation. The showings have been prospected by means of a short adit and a number of pits. According to local reports, a few tons of sorted ore, averaging about 30 percent $\mathrm{Mn}$, were shipped from these prospects.

\section{PLACER DEPOSITS}

Placer gold has been mined sporadically since 1870 from bench gravel and valley-bottom alluvium at several places along and near Indian Creek between its mouth and Hassel, an abandoned mining village along the creek 3 miles west of the map area. During 1940-42 an electric-powered dragline dredge operated by the Cooley Gravel, Co. recovered about 10,050 ounces of gold in the area mapped (Leyden, 1948 , p. 19-20), probably mostly from valley-bottom alluvium. Leyden's data indicate an average recovery of about 22 cents worth of gold $(0.0063 \mathrm{oz}$.) per yard of gravel mined during 1940 and 1941. No record of the earlier output from this area, achieved by hand methods, is available, but it probably did not exceed the 1940-42 output.

The placer gold was undoubtedly derived from the Diamond Hill and other lode deposits near Hassel (Reed, 1951, p. 44-45). Part of the gold was deposited originally with gravel in channels as much as 40 feet deep in a pediment, remnants of which are exposed in sec. 28, T. 7 N., R. 1 E. (pl. 42), and probably also in the fan to the east, which may have been accumulating as the pediment was being dissected, probably during the Pleistocene. Gold in the Recent valley-bottom alluvium is probably partly reconcentrated from the gravel channels in the pediment and fan, which are being dissected, and is partly material recently eroded from lode sources farther up Indian Creek. Judging from the workings in the fan, some of the older 
deposits formed directly on bedrock and some formed above "false bedrock." Unexploited auriferous channels probably exist in the Indian Creek fan and the underlying pediment.

In earlier years, placers a mile west of the area mapped, near Radersburg, yielded between $\$ 500,000$ and $\$ 1$ million worth of gold (Winchell, 1914, p. 182; Leyden, 1948, p. 20). A few small excavations in the marginal part of this placer district are half a mile northwest of Parker at the west edge of the mapped area. The gold was in a thin veneer of gravel that capped a pediment surface cut on the Oligocene sedimentary tuff and in gravels along the drainages dissecting the pediment surface. The gravels probably ranged in age from late Pliocene to Recent. The gold was eroded from lodes in the Radersburg mining district $1 \frac{1}{2}$ miles west of the map area (Corry, 1933, p. 19-23).

\section{MANGANESE DEPOSITS IN TERTLARY ROCKS}

A hard black manganese mineral, probably psilomelane, impregnates and incrusts unconsolidated or weakly consolidated sand and gravel that is part of the lower Oligocene sedimentary-tuff sequence or weathered material overlying the tuff at several places near the western margin of the broad area of Tertiary rocks about $4 \frac{1}{2}$ miles north of Wheatland School. The best exposed deposit is along a trail that marks the boundary between secs. 26 and $27, T .4$ N., R. 1 W. It is a conical mound about 100 feet in diameter and 15 feet high capped by a botryoidal crust ranging from several inches to more than 1 foot in thickness of sand and fine gravel cemented by dense manganese oxide. Though some thin seams of pure manganese mineral are present, the bulk of the material is about half sand and gravel and half manganese mineral. About 1,000 feet to the north and at the same elevation are a few small outcrops of similar material that appear to be at about the same stratigraphic position. The same type of material occurs in float at or near the concealed contact between the Elkhorn Mountains volcanics and Oligocene sedimentary tuff in the SWY/4 of sec. 14, T. $4 \mathrm{~N}$., R. $1 \mathrm{~W}$.

The manganese mineral is blue black with a very dark brown streak, has a hardness of about 5 , and is massive with a tendency to form botryoidal crusts or concretionary growths. Though the test for barium is weak, it is positive, and the mineral is probably best classified as psilomelane.

It is not clear whether the manganese was deposited by springs after the pediment had been formed or whether it was deposited as the Oligocene beds accumulated, perhaps in local bogs or perhaps from springs, and that the resistant manganese-cemented material locally eroded in relief during the cutting of the pediment. 
Manganese deposits of this type in the area mapped are few, small, relatively low grade, and are not likely to be of commercial importance.

\section{FAVORABILITY FOR URANIUM}

During March 1955 a.number of uranium deposits were discovered in Tertiary rocks in the Canyon Ferry quadrangle, 0.5 to 3 miles north of the map area of this report. Some of the deposits consist of a yellow uranium-vanadium mineral, probably carnotite, along fractures or replacing woody fragments in acidic tuff and sedimentary tuff, and some are thin beds of radioactive carbonaceous tuffaceous shale or impure lignite in which no uranium minerals have been identified G. E. Becraft, 1958). The known deposits are in the lower part of a bentonite-bearing unit of Oligocene age (Tertiary unit 2 of Mertie, Fischer, and Hobbs, 1951, p. 33-35 and pls. 1 and 2). The bentonitebearing unit is in the middle part of a sequence between 6,000 and 10,000 feet thick composed mainly of acidic volcanic debris of local derivation that settled in ponds or was partly reworked and transported by streams (Mertie, Fischer, and Hobbs, 1951, p. 29).

The bentonite-bearing unit (pl. 42 , unit $\mathrm{Tu}_{2}$ ) trends southward and dips, on the average, about $25^{\circ} \mathrm{E}$. It has been traced and mapped about a mile south of the north boundary of the area. Farther to the south, in the unit mapped as Tertiary undifferentiated (Tun), the Tertiary rocks are largely covered by mantle, and the bentonitebearing unit may be overlain wholly or in part by unconformable Tertiary beds. Bentonite-bearing Oligocene beds that may be correlative with unit $\mathrm{Tu}_{2}$ also occur in a north-trending belt between Lone Mountain and Wheatland School. In this belt the beds dip, on the average, about $10^{\circ} \mathrm{E}$.

Oligocene rocks in the Townsend Valley area in general, and bentonitic and carbonaceous units in particular, are considered favorable for the occurrence of uranium. Perhaps the most promising part of the area is in the northwest corner of the map area where acidic volcanic debris accumulated rapidly and was not extensively reworked, and where carbonaceous material accumulated locally in swamps or ponds. Within favorable units uranium is most likely to be localized in carbonaceous rocks or in alternations of permeable and impermeable beds. Though the discoveries to date have been confined to the bentonite-bearing unit, favorable sites for localization of uranium may occur elsewhere in the sequence of Tertiary rocks. Perhaps the best clues to favorable sites for uranium are the presence of carbonaceous material, a preponderance of volcanic material that has not 
been reworked, an interlayering of permeable and impermeable rocks, and the presence of faults. The Miocene or Pliocene rocks, most of which are east of the Missouri River, are probably less favorable than the Oligocene rocks because they consist largely of reworked material.

\section{. NONMETALIIC DEPOSITS}

Building stone, quartzite for use in cement, and gravel for use as road metal, have been produced from the area. In the southern Limestone Hills, the mottled and banded limestone of the upper part of the Meagher limestone was formerly quarried as a building stone. The quarry in sec. 4, T. 5 N., R. 1 E. was operated by the Vermont Marble Co. between 1928 and 1930 and for about 3 months in 1937. The limestone was used primarily as a base under other marble die, although some was used for decorative purposes. Other limestone, dolomite, and quartzite units in the Paleozoic formations are probably suitable structurally for building stone but are not as attractive in appearance as the upper part of the Meagher limestone.

The Flathead quartzite is a relatively pure quartz sandstone and is therefore usable as silica in the production of special types of cement. During part of 1948-49, 6,200 tons of quartzite was quarried at one locality in the Limestone Hills (NW1/4 of sec. 27, T. 6 N., R. 1 E.) and trucked to a cement plant at Trident, Mont. (Russel Stewart, written communication).

Gravel from the fans and alluvium have been used locally by the Montana State Highway Department and by private individuals for road metal. No permanent plant for crushing and washing has been built in the area of this report.

Impure bentonite occurs in Tertiary unit 2 along the northern edge of the map area and in a belt south of Lone Mountain. Though the bentonite deposits in the area of this report have not been studied in detail, they appear to be generally similar to the deposits that have been studied in the Canyon Ferry quadrangle to the north (Mertie, Fischer, and Hobbs, 1951, p. 89-90) but are probably not as suitable for exploitation.

Thin beds of diatomaceous earth are present in the upper part of Tertiary unit 2 in the Canyon Ferry quadrangle (Mertie, Fischer, and Hobbs, 1951, p. 35). Similar material might occur in the area mapped, particularly in Tertiary unit 2 and in the bentonitic part of the lower Oligocene unit (To) between Lone Mountain and Wheatland School. 


\section{STRATIGRAPHIC SECTIONS}

Section of Belt rocks in northern part of Limestone Hills (measured from SE1/4NW1/4 sec. 3 to a point $800 \mathrm{ft}$. west of mutual corners of secs. 1, 2, 11, and 12, T. 6 N., R. 1 E.)

Flathead quartzite:

24. Quartzite, light-colored, clean. Not measured. Empire shale(?):

23. Siltstone and argillite, dark-gray, laminated, very poorly exposed. Upper half of interval covered with float of Flathead quartzite..

Thickness $($ feet)

Spokane shale:

22. Argillite and siltstone, mainly dark-grayish-red, poorly exposed. Beds in upper $90 \mathrm{ft}$ are predominantly dark gray, weathers greenish gray. Transitional into Empire shale(?) ........

21. Argillite, siltstone, and subordinate shale; mainly grayish red but contains some greenish-gray, yellowish-gray and purple beds, partly laminated; mud cracks and mica flakes present along some

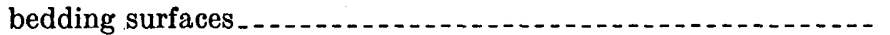

20. Argillite and siltstone, similar to that in unit 18..............

19. Diabase sill (see pl. 42)

18. Argillite and siltstone, mostly dark gray and medium dark gray;

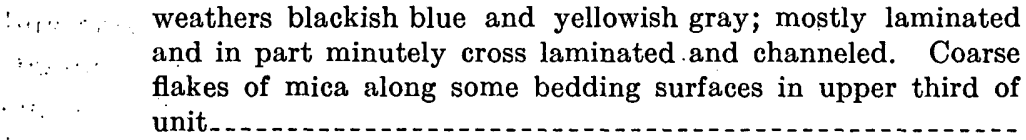

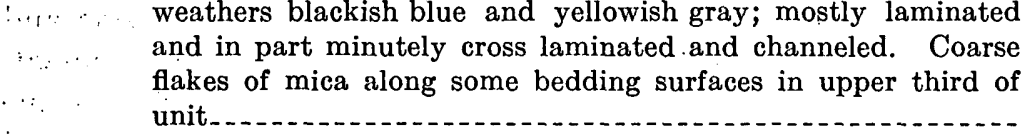

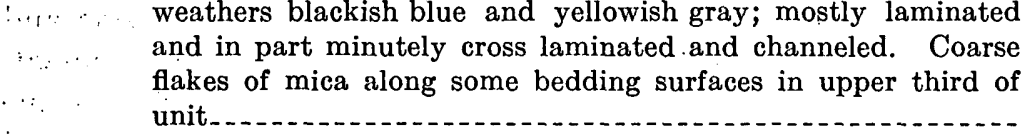

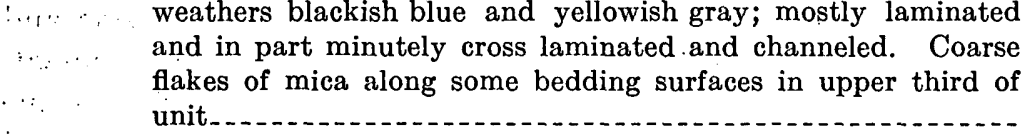

17. Diabase sill (see pl. 42)

16. Siltstone and argillite, dusky-red, purple, purplish-black, and very subordinately light-greenish-gray; in part laminated..........

15. Diabase sill . . . . . . .

14. Argillite and siltstone, grayish-red and light-greenish-gray, with some dusky-red beds near top; laminated to thin bedded.......

13. Limestone, medium-gray and light-greenish-gray; weathers moderate yellowish brown; clayey, laminated.................

12. Argillite and siltstone, mainly grayish-red but with 10 to 20 percent light-greenish-gray beds in lower $250 \mathrm{ft}$ of unit; shaly partings are common, contains a few thin beds of limestone and ripple-marked, laminated clean quartzite

Total thickness of Spokane shale (excluding sills)

Greyson shale (including beds transitional into Spokane shale):

11. Argillite and siltstone, greenish-gray, grayish-red, and subordinately dusky-yellow; mostly laminated, in part ripple-marked; several thin beds of light-gray clean fine-grained sandstone, mainly in upper $90 \mathrm{ft}$, and two thin limestone beds

10. Limestone, crinkly, laminated, with subordinate argillite........

9. Argillite and subordinate siltstone, about half grayish-red and half greenish-gray and olive-gray; mostly laminated, some beds ripple marked, a few thin beds of quartzite....................

8. Siltstone, greenish-gray, shaly; few greenish-red beds in upper half of unit; a few thin beds of laminated quartzite and one thin bed of limestone. Base of transition zone to overlying Spokane shale.

7. Shale and siltstone, light-olive-gray and greenish-gray, limy; two thin impure limestone beds in upper third of unit....... 
Section of Belt rocks in northern part of Limestone Hills (measured from $S E^{1} 4_{4} N W Y / 4$ sec. 3 to a point $800 \mathrm{ft}$. west of mutual corners of secs. $1,2,11$, and $18, T .6 \mathrm{~N}$., R. 1 E.)-Continued

Greyson shale-Continued

Thickness

6. Siltstone and shale, dusky-yellow, light-olive, and medium-greenish-gray, laminated; a few thin beds of shale-chip conglomerate near top of unit.

5. Quartzite and siltstone; quartzite is fine grained, very light gray, well sorted, and in beds 1 in. to $1 \mathrm{ft}$ thick; siltstone is light gray, dirty, and laminated. Resistant unit

4. Shale, and subordinate siltstone, olive-gray and dark-greenishgray; shale is in part silty, fissile to chippy, and contains a few thin carbonaceous(?) seams; siltstone is shaly and thin bedded.-

3. Sandstone, siltstone, and subordinate shale; predominantly light olive gray; sandstone is very fine grained with well sorted and rounded quartz grains. Resistant unit...................

2. Siltstone and shale; mainly light-olive-gray to olive-gray but partly dark-gray and dark-greenish-gray; alternating thick and thin beds of blocky jointed siltstone and thinly laminated shale; iron stain and thin quartz veins locally abundant................

1. Shale and siltstone, probably similar to unit 2 , mostly concealed. Thickness to oldest exposed beds at crest of anticline at least...

Total thickness of Greyson shale (including transition beds between typical Greyson and Spokane) at least

Section of Belt rocks in southern part of Limestone Hills (measured from SEY/4 NE1/4 sec. 39 to $S W 1 / 4 W_{1 / 4}^{1 / 4 e c}$. 26, T. 6 N., R. 1 E.)

Flathead quartzite. Not measured.

Spokane shale:

Thickne 8s (feet)

9. Argillite, with some siltstone and shale, mainly grayish red; lower $185 \mathrm{ft}$ is dark grayish red; contains a few yellowish-gray streaks from $2,100 \mathrm{ft}$ to $2,400 \mathrm{ft}$ above base. Upper $300 \mathrm{ft}$ mostly covered, but no rock similar to the Empire shale was observed in float

8. Argillite, with some siltstone and shale, blackish-purple, becoming lighter and containing a few green interbeds near top.........

7. Diabase sill. Not measured.

6. Argillite, with subordinate siltstone and shale; predominantly grayish red, but in part greenish gray, blackish red, and purple.

5. Limestone, argillaceous; probably of algal origin...........

4. Argillite, grayish-red; contains a few thin beds of quartzite and limestone and some green shale in lower $400 \mathrm{ft}$. Approximate correlative of unit 12 in northern Limestone Hills section ..... . 1, 250

Total thickness of Spokane shale

Greyson shale (upper part, including beds transitional into Spokane shale):

3. Siltstone and argillite, grayish-red and olive; upper $90 \mathrm{ft}$ of unit consists of grayish-red argillite, olive siltstone, quartzite, and limy crossbedded siltstone. Unit is transitional from Greyson to Spokane 
Section of Belt rocks in southern part of Limestone Hills (measured from $S E 1 / 4 N E 14$ sec.' 39.to SW14SW14 sec. 26, T. 6 N., R. 1 E.) -Continued

Greyson shale-Continued

Thickness (feet)

2. Siltstone, olive and grayish-green; mostly laminated and subordinate impure sandy limestone near base and top; contains a few thin beds of grayish-red shale in upper $75 \mathrm{ft}$. Probable correlative of units 7 and 8 in northern Limestone Hills section......

1. Siltstone, pale-olive, laminated; several thin beds of fine-grained quartzite and shale. Probable correlative of units 5 and 6 in northern Limestone Hills section..._.

Greyson shale (upper part only)

Section of Cambrian and Devonian rocks in Hossfeldt Hills (measured along north slopes of main gulch in $S \$ 2$ sec. 9, T. 3 N., R. 2 E., Broadwater County, Mont., about 1 mile east of map area)

Jefferson dolomite:

24. Dolomite, white, medium-crystalline. Uppermost outcrops thought to indicate approximate top of formation . . .........

23. Dolomite, as in unit 17, thin bedded in lower part, thick bedded

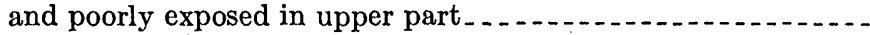

22. Mostly concealed. Float is mainly typical dolomite as in unit 17; several thin zones of dolomite breccia and orange-stained dolomite (solution breccia?) and near the top one 12-foot-thick unit of white medium-crystalline limestone are poorly exposed ....- -

21. Dolomite, as in unit 17 , thin-bedded, poorly exposed, sheared at top; displacement, if any, slight.

20. Dolomite, as below, but with abundant irregular chert seams;

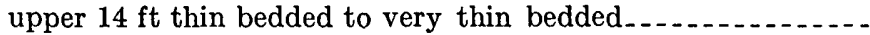

19. Dolomite, massive; similar to that in unit 17

18. Mostly concealed. Float is mainly thin bedded dolomite similar to that in unit 17; some pieces are light-gray limestone.......

17. Dolomite, dark-brownish-gray, fetid, medium-crystalline, very thin- to thin-bedded in lower $14 \mathrm{ft}$, mostly thick-bedded to massive above; chert is sparsely present as irregular films and as nearly spheroidal nodules as much as 2 in. in diameter, some with calcite centers. Brachiopods $9 \mathrm{ft}$ above base

16. Concealed interval. Float is dolomite similar to that in unit 17.

Total thickness of Jefferson dolomite

Red Lion and Maywood formations, undivided:

15. Covered interval. Float is mixed limestone, siltstone, and very fine grained sandstone. Predominant colors are light brown and grayish yellow

14. Siltstone and limestone. Alternation of 3 units of limy yellowishgray, locally orange and red-stained, very thin bedded siltstone and 2 units of gray- to grayish-yellow thinly ribboned limestone.

13. Concealed interval

Total thickness of Red Lion and Maywood formations........ 
Section of Cambrian and Devonian rocks in Hossfeldt Hills (measured along north slopes of main gulch in S 12 sec. 9, T. 3 N., R. 2 E., Broadwater County, Mont., about 1 mile east of map area-Continued

Pilgrim dolomite:

Thickness (feet)

12. Dolomite, similar to unit 10 , massive and very indistinctly

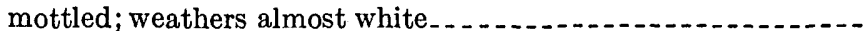

11. Dolomite, similar to unit 10 but thin bedded.....................

10. Dolomite, yellowish-gray and dark-olive-gray, medium-crystalline; thick bedded to massive except for a few thin beds; indistinctly. mottled on weathered surface

9. Limestone, yellowish-gray and medium-gray, thin-bedded; with ribbons up to $0.75 \mathrm{in}$. thick of granular to very finely crystalline grayish-yellow limestone; upper beds are thicker bedded dolomite; some float pieces are glauconitic

8. Largely concealed. Mostly and perhaps entirely underlain by ribboned limestone similar to that in unit 9

7. Dolomite, poorly exposed, dark-olive-gray, slightly limy, finely granular, in part faintly mottled and yellow; in beds as much as $1.5 \mathrm{ft}$ thick. Contains some thin beds of oolitic limestone....-

Total thickness of Pilgrim limestone

Park shale:

6. Concealed.

Meagher limestone:

5. Limestone, dark-gray, similar to unit 3; irregular mottles or ribbons are grayish orange and tend to cut bedding but are concentrated in groups that parallel bedding; locally contains sparse pyrite cubes and fossil fragments..........

4. Limestone, similar to unit 3 but ribbons are few and less continuous and bedding is less distinct. Unit is relatively massive...

3. Limestone, dark-gray, very finely crystalline; in beds $0.02-$ to $0.2-\mathrm{ft}$ thick, with conspicuous irregular ribbons, mostly roughly parallel to bedding, up to $0.25 \mathrm{in}$. thick, of olive-gray finely crystalline limestone or very limy siltstone.

Total thickness of Meagher limestone

Wolsey shale:

2. Mostly covered. A few outcrops of glauconitic medium-grained sandstone at base, and dark-greenish-gray laminated micaceous silty shale with irregular trail-like markings on bedding

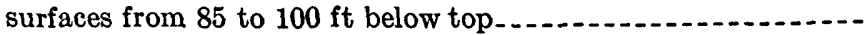

Flathead quarzite:

1. Quartzite, very pale orange; lower part weathers light brown and grayish red. Individual beds consist of moderately well sorted, fine to coarse, rounded to subrounded quartz grains. Thin bedded to thick bedded, cross laminated to very thinly cross

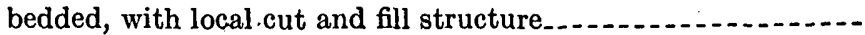

Spokane shale. Not measured. 
Section of the Wolsey shale in Limestone Hills (measured in SE1/4 sec. 34, T. 7 N.,

\section{, R. 1 E.)}

Meagher limestone:

26. Limestone, pale-yellowish-brown to light-olive-gray, finely crystalline and dense; irregular thin color bands parallel bedding.-..Wolsey shale:

25. Mudstone, light-olive-gray, dense, blocky to platy; in irregular beds about $0.04 \mathrm{ft}$ thick; some interbedded fine-grained sandstone or coarse siltstone; unit weathers moderate brown to dark yellowish orange; mildly metamorphosed

24. Mudstone, light-olive-gray to medium-dark-gray, platy, blocky, or fissile; in part very finely micaceous; in part laminated with laminae conspicuous only on fresh surface; irregularly bedded, with subordinate beds of coarse siltstone or very fine grained sandstone; unit weathers moderate brown to dark yellowish

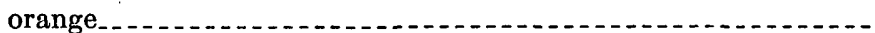

23. Sandstone, quartzitic, very fine grained.

22. Concealed quartzitic very fine graind

21. Mudstone; similar to unit 24

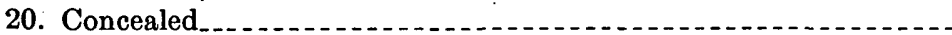

19. Sandstone, pale-yellowish-brown to pale-brown, argillaceous, slightly calcareous, very fine grained; speckled with small limonite grains; in irregular beds averaging $0.1 \mathrm{ft}$ in thickness; locally contains irregular and nonpersistent laminae of dark-gray siltstone . . . .

18. Concealed ..............

17. Sandstone; similar to unit 19

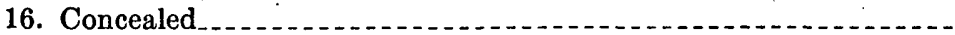

15. Shale, gray to grayish-black, platy to fissile, coarsely micaceous, laminated; weathers moderate brown

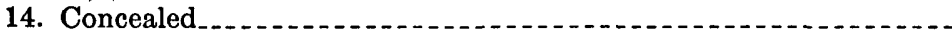

13. Shale, similar to unit 15 , but medium-dark-gray and not conspicuously laminated; mildly metamorphosed.......... 5

12. Concealed......... 10

11. Shale, similar to unit $13 \ldots$

10. Sandstone, brownish-gray, quartzitic, slightly limonitic, very fine grained. . . . . . .

9. Concealed

8. Sill, granodiorite, finely crystalline

7. Sandstone, pinkish-gray to pale-red, quartzitic, fine-grained; speckled with small limonite grains; sparsely micaceous on some bedding planes; some interbedded gray- to grayish-black, platy to fissile, coarsely micaceous siltstone.................

6. Sandstone, pinkish-gray to pale-red, quartzitic, fine-grained; speckled with small limonite grains; sparsely micaceous on some bedding planes

5. Siltstone, gray, coarse-grained; weathers grayish brown to moderate brown; mildly metamorphosed. . . . . . . . . . . . . .

4. Concealed

3. Sill, granodiorite, finely crystalline $\ldots \ldots \ldots \ldots \ldots$ 
Section of the Wolsey shale in Limestone Hills (measured in $S E Y_{4}$ sec. $34, T .7$ N., R. 1 E.)-Continued

Wolsey snale-Continued

Thickness

2. Siltstone, medium-gray to dark-gray, very micaceous; irregularly laminated with laminae ranging from 0.03 to $0.1 \mathrm{in}$. in thickness and from medium gray to dark greenish gray; weathers medium dark gray; mildly to moderately metamorphosed............

Total thickness of Wolsey shale (excluding sills) . . . . . . . . .

Flathead quartzite:

1. Sandstone, grayish-orange-pink, grayish-pink, and pale-red, medium-grained, quartzitic, vitreous, dense, homogeneous; weathers reddish brown, dark yellowish orange, and moderate dark yellowish brown

Section:of the Red Lion and Maywood formations in Limestone Hills (measured in $S W 34$ sec. $34, T .7$ N., R. 1 E.)

Jefferson dolomite:

Thickness (feet)

10. Dolomite, calcareous, or dolomitic limestone, medium-dark-gray, finely crystalline; in indistinct beds about $6 \mathrm{ft}$ thick, with one bed $3.7 \mathrm{ft}$ thick of yellowish-gray to dark-yellow limestone at

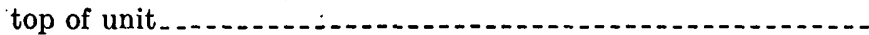

Red Lion and Maywood formations:

9. Limestone, light-olive-gray and medium-gray to medium-lightgray, dolomitic, finely crystalline; a few breccia layers in upper part; weathers yellowish gray to light gray ..............

8. Limestone, dolomitic, or calcareous dolomite, medium-gray at base and yellowish-gray and light-gray at top; finely crystalline, massive to medium bedded; $p$ contains sparsely scattered darkyellowish-orange siltstone chips near base; weathers yellowish

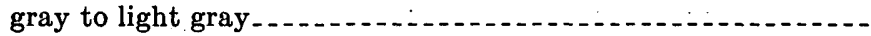

7. Limestone, medium-light-gray, very finely crystalline, dolomitic, platy; contains yellowish-gray to grayish-yellow bands and mottles up to 1 in. thick, averaging 0.25 to 0.5 in ..........

6. Limestone, pale-yellowish-orange to grayish-orange, dolomitic; medium-bedded and weathers very pale orange at base; thickbedded and weathers yellowish-gray to light-gray at top.......

5. Limestone, dolomitic, or calcareous dolomite, yellowish-orange, moderately silty, chippy to almost platy; in beds 0.1 to $0.3 \mathrm{ft}$ thick; weathers very pale yellowish orange................

4. Concealed.

3. Dolomite, yellowish-orange, very finely crystalline; in beds 0.5 to $0.7 \mathrm{ft}$ thick; weathers very pale orange to yellowish orange....-

2. Concealed; in upper $10 \mathrm{ft}$ float is pale-red, pale-reddish-brown, and moderate-yellowish-brown, chippy to chunky, slightly dolomitic "siltstone that weathers light brown, grayish orange pink, and"grayish orange; lower $38.8 \mathrm{ft}$ of unit entirely concealed but

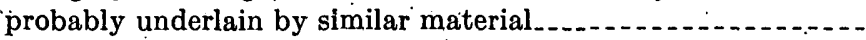

Total thickness of Red Lion and Maywood formations......

1. Dolomite, medium-light-gray to very light gray medium crystalline, homogeneous, thick- and indistinctly bedded; very indistinctly mottled with various shades of gray in lower part; weathers light to very light gray and is characteristically a ridge former 
Section of the Jefferson dolomite in Limestone Hills (measured in SW14 sec. 34, T. 7 N., R. 1 E.)

Three Forks shale:

25. Concealed

Jefferson dolomite:

24. Dolomite, medium-gray to medium-dark-gray, finely crystalline, fetid, thick- and indistinctly bedded; contains scattered pseudomorphs of iron oxide after pyrite 2 to $6 \mathrm{ft}$. below top of unit..--

23. Dolomite, medium-gray, finely crystalline; laminated with bands of slightly different color commonly less than 0.04 in. thick; in part platy, in beds from 0.5 to $0.8 \mathrm{ft}$. thick; weathers medium light gray to medium gray

22. Concealed, underlain by medium-dark-gray to dark-gray, finely crystalline, fetid dolomite; thin calcite seams common .......-

21. Concealed, abundant chips of yellowish-orange silty dolomitic limestone in soil in upper 10 to $15 \mathrm{ft}$. of unit; one bed of yellowish-gray to medium-light-gray limestone or dolomitic limestone about 22 feet above the base of the unit.

20. Dolomite, medium-dark-gray to dark-gray, finely crystalline; contains inconspicuous calcite seams. and sporadic patches or clusters of crystalline calcite; thick-and indistinctly bedded at base becoming distinctly medium-bedded in middle of unit....-

19. Concealed, one bed $2 \mathrm{ft}$ thick of medium-dark-gray dolomite 23.4 to $25.4 \mathrm{ft}$ above the base of the unit.

18. Dolomite, medium-gray, finely crystalline; a lenticular bed of intraformational conglomerate 0.5 to $1 \mathrm{ft}$ thick composed of mixed dolomite fragments occurs 4.5 to $5.5 \mathrm{ft}$ above the base of the unit.

17. Concealed.

16. Dolomite, dark-gray, finely crystalline, fetid, distinctly bedded.-

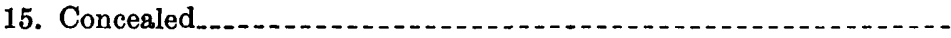

14. Dolomite, light-to-medium-light-gray, finely crystalline, fetid, indistinctly bedded; contains lenticular breccia zone composed of fragments of similar dolomite as much as 3 in. in maximum dimension.

13. Dolomite, dark-gray, finely crystalline, very fetid; distinct beds 0.7 to $2 \mathrm{ft}$ thick; contains some interbeds of medium-gray to medium-light-gray dolomite; weathered surface rough.........

12. Dolomite, light-gray and medium-gray; contains interbeds of similarly colored calcareous dolomite; unit thick- and indistinctly bedded; predominantly light gray in lower 8 to $12 \mathrm{ft}$, darker in upper $10 \mathrm{ft}$.

11. Dolomite, medium-gray; indistinct beds 0.7 to $2 \mathrm{ft}$. thick; conspicuous color banding 33.4 to $36.0 \mathrm{ft}$. above the base of the unit; a 5-foot concealed zone 2.1 to $7.1 \mathrm{ft}$. above base; weathers variably from medium light to medium gray with a few scattered irregular to ovoid siliceous encrustations on weathered surfaces.-

10. Concealed, abundant dark dolomite and yellowish-orange silty dolomitic limestone chips in soil. 
Section of the Jefferson dolomite in Limestone Hills (measured in SW1/4 sec. S4; S. 7.N., R. 1 E.)-Continued

Jefferson dolomite-Continued

9. Dolomite, medium-dark-gray, finely crystalline, distinctly bedded in beds 0.7 to $1 \mathrm{ft}$ thick; locally contains a few calcite stringers less than $0.05 \mathrm{in}$. thick; weathers to rough medium-dark-todark-gray surface. . . .

8. Dolomite, medium-gray

7. Dolomite, similar to unit 9 , with irregular branching markings as much as $2 \mathrm{in}$. long and $0.5 \mathrm{in}$. wide at the base of the unit.-

6. Dolomite; similar to unit 9

5. Limestone, medium-gray, finely crystalline; contains two thin dolomite beds; weathers medium gray to medium light gray.-.-

4. Dolomite, medium-dark-gray in lower $10.3 \mathrm{ft}$, medium-gray in upper $14.2 \mathrm{ft}$, finely crystalline; contains scattered small siliceous patches on weathered surfaces; unit weathers.medium dark gray in lower 10.3 feet and medium gray to medium light gray in upper $14.2 \mathrm{ft}$

3. Dolomite, medium-dark-gray; commonly thick- and indistinctly bedded; contains siliceous zone 19.7 to $23.7 \mathrm{ft}$ above the base of the unit

2. Dolomite, calcareous or dolomitic limestone, medium-dark-gray, finely crystalline, in indistinct beds about $6 \mathrm{ft}$ thick; one bed $3.7 \mathrm{ft}$ thick of yellowish-gray to dark-yellow limestone at top.-.

Total thickness of Jefferson dolomite

Red Lion and Maywood formations:

1. Limestone, light-olive-gray and medium-gray to medium-lightgray, dolomitic, finely crystalline; contains a few breccia layers in upper part; unit weathers yellowish gray to light gray......

Section of the Three Forks shale in Limestone Hills (measured in SE1/4 sec. $39, T .7$ N., R. 1 E.)

Lodgepole limestone:

23. Limestone, medium-dark-gray, dense-to-medium crystalline except lower $4 \mathrm{ft}$ which is coarsely crystalline and very fossiliferous; in part distinctly bedded in beds 0.1 to $1 \mathrm{ft}$, averaging 0.2 to $0.3 \mathrm{ft}$ thick; in part with a hackly fracture more or less parallel to bedding; weathers medium gray with a bluish, and in

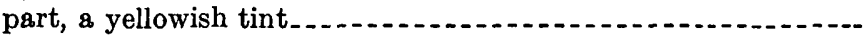

Three Forks shale:

22. Sill, granodiorite

21. Siltstone, very calcareous, medium-gray, almost fissile. .........

20. Siltstone, very calcareous, poorly fissile; weathers between pale yellowish orange and moderate yellowish brown with pale-red and medium-gray patches.

19. Limestone, medium-gray to medium-light-gray, finely crystalline, silty, thinly but conspicuously laminated; weathers light olive

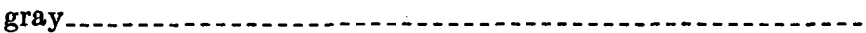

18. Siltstone; similar to unit 20

17. Sill, granodiorite

16. Siltstone; similar to unit 20.

15. Shale, very calcareous, fissile; weathers between pale yellowish orange and moderate yellowish brown with pale-red and medium-

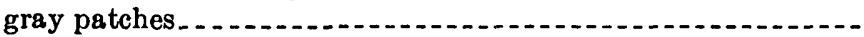


Section of the Three Forks shale in Limestone Hills (measured in SE1/4 sec. $39, T .7$ $N ., R, 1$ E.) -Continued

Three Forks shale-Continued

Thickness Feet

14. Concealed ......... 10

13. Shale, yellowish-gray, moderately calcareous, thinly platy to

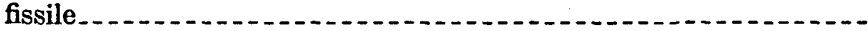

12. Concealed

11. Limestone, medium-light-gray with irregular yellowish-orange areas; crumbly, in part blocky, in part fissile; contains abundant fossil fragments.

10. Concealed

9. Sill, covered by granodiorite float. .

8. Concealed............ 104

7. Concealed; predominantly gray, fissile shale float._......... 42

6. Shale, dark-gray, extremely fissile, papery; pencilly near top of unit; contains some 0.3 to $0.4 \mathrm{ft}$ beds of moderate-yellowishbrown, moderately calcareous, sparsely pyritic, coarse-grained siltstone

5. Concealed; gray papery shale float similar to the shale in unit 6 --

4. Shale, similar to shale in unit 6 but medium dark gray

3. Concealed; gray papery shale float similar to that in unit $6 . . . .$.

2. Concealed... 60

Total thickness of Three Forks shale (excluding sills) _..... 360

Jefferson dolomite:

1. Dolomite, medium-gray to medium-dark-gray, finely crystalline, fetid, thick- and indistinctly bedded; contains scattered pseudomorphs of iron oxide after pyrite 2 to $6 \mathrm{ft}$ below top of unit...-

Section of the Amsden formation in Limestone Hills (measured in SEY4 sec. 29 T. 6 N., R. 1 E.)

Quadrant formation:

12. Quartzite, light-gray to medium-light-gray, clean, vitreous, finegrained; weathers yellowish brown.......

Amsden formation:

11. Concealed.

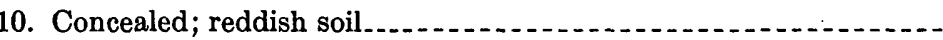

9. Concealed; abundant chips of moderate-red to pale-reddish-brown

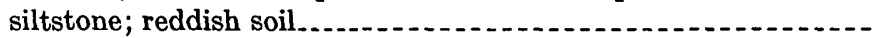

8. Dolomite, medium-light-gray, finely crystalline; one 0.3-foot bed of intraformational breccia occurs $4 \mathrm{ft}$ above base of unit......

7. Concealed...........

6. Limestone, light-gray to light-olive-gray, medium finely crystalline; contains sporadic small calcite crystals and fossil fragments

5. Concealed.

4. Limestone, medium-light-gray, very finely crystalline; in beds 0.7 to $1 \mathrm{ft}$ thick; contains sporadic chert nodules as much as $0.3 \mathrm{ft}$. in diameter.

3. Concealed............. 46

2. Concealed; red siltstone float............. 99

Total thickness of the Amsden formation 
Section of the Amsden formation in Limestone Hills (measured in SEY/4 sec. 29 T. 6 N., R. 1 E.)-Continued

Mission Canyon limestone:

1. Limestone, medium-gray to medium-light-gray, finely crystalline, slightly fetid, massive; contains sporadic siliceous encrustations; top of unit marked by a bed of limestone breccia 0.2 to $1 \mathrm{ft}$ thick;

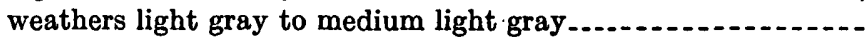

\section{LITERATURE CITED}

Atwood, W. W., 1916, The physiographic conditions at Butte, Mont., and Bingham Canyon, Utah, when the copper ores in these districts were enriched: Econ. Geology, v. 11, p. 697-740.

Beales, F. W., 1953, Dolomitic mottling in Palliser (Devonian) limestone, Banff and Jasper National Parks, Alberta: Am. Assoc. Petroleum Geologists Bull., v. 37, p. 2281-2293.

Becraft, G. E., 1958, Uranium in carbonaceous rocks in the Townsend and Helena Valleys, Mont.: U. S. Geol. Survey Bull. 1046-G.

Berry, G. W., 1943, Stratigraphy and structure at Three Forks, Mont.: Geol. Soc. America Bull., v. 54, p. 1-30.

Cobban, W. A., 1945, Marine Jurassic formations of the Sweetgrass Arch. Montana: Am. Assoc. Petroleum Geologists Bull., v. 29, p. 1262-1303.

Cobban, W. A. and Reeside, J. B., Jr., 1951, Lower Cretaceous ammonites in Colorado, Wyoming, and Montana: Am. Assoc. Petroleum Geologists Bull., v. 35, p. $1892-1893$.

- 1952, Correlation of the Cretaceous formations of the western interior of the United States: Geol. Soc. America Bull., v. 63, p. 1011-1044.

Collier, A. J., and Cathcart, S. H., 1922, Possibility of finding oil in laccolithic domes south of the Little Rocky Mountains, Mont.: U. S. Geol. Survey Bull 736.

Condit, D. D., 1918, Relations of late Paleozoic and early Mesozoic formations of southwestern Montana and adjacent parts of Wyoming: U. S. Geol. Survey Prof. Paper 120-F.

Corry, A. V., 1933, Some gold deposits of Broadwater, Beaverhead, Phillips, and Fergus Counties, Mont.: Mont. Bur: Mines and Geology Mem: 10.

Darton, N. H., 1904, Comparison of the stratigraphy of the Black Hills, Bighorn Mountains, and Rocky Mountain Front Range: Geol. Soc. America Bull., v. 15, p. $379-448$.

Deiss, C. F., 1936, Revision of type Cambrian formations and sections of Montana and Yellowstone National Park: Geol. Soc. America Bull., v. 47, p. 12571342.

Eldridge, G. H., 1896, Geology of Denver Basin in Colorado: U. S. Geol. Survey Mon. 27.

Emmons, W. H. and Calkins, F. C., 1913, Geology and ore deposits of the Philipsburg quadrangle, Montana: U. S. Geol. Survey Prof. Paper 78.

Fischer, C. A., 1909, Geology of the Great Falls coal field, Montana: U. S. Geol. Survey Bull. 356.

Freeman, V. L., 1954, Geology of part of the Johnny Gulch quadrangle, Montana, U. S. Geol. Survey Open File Report.

Hanson, A. M., 1952, Cambrian stratigraphy in southwestern Montana: Mont. Bur. Mines and Geology Mem. 33.

Hayden, F. V., 1876, U. S. Geol. and Geog. Survey Terr. 8th Ann. Rept. 
Haynes, W. P., 1916, The Lombard overthrust and related geological features: Jour. Geology, v. 24, p. 269-290.

Iddings, J. P., and Weed, W. H., 1894, Livingston, Mont.: U. S. Geol. Survey Geol. Atlas, folio 1.

Imlay, R. W., 1948, Characteristic marine Jurassic fossils from the western interior of the United States: U. S. Geol. Survey Prof. Paper 214-B.

Klepper, M. R., 1951, Geology of the southern Elkhorn Mountains, Jefferson and Broadwater Counties, Mont.: U. S. Geol. Survey Open File Report.

Klepper, M. R., Weeks, R. A., and Ruppel, E. T., 1957, Geology of the southern Elkhorn Mountains, Mont.: U. S. Geol. Survey Prof. Paper 292, [1958].

Knopf, Adolph, 1936, Igneous geology of the Spanish.Peaks region, Colo.: Geol. Soc. America Bull., v. 47, p. 1727-1784.

Leyden, C. J., 1948, The gold placers of Montana: Mont. Bur. Mines and Geology Mem. 26.

Lochman, Christina, 1950, Status of Dry Creek shale of central Montana: Am. Assoc. Petroleum Geologists Bull., v. 34, p. 2200-2222.

Lorenz, H. W., and McMurtrey, R. G., 1956, Geology and occurrence of ground water in the Townsend Valley, Mont.: U. S. Geol. Survey Water-supply paper 1360-C.

McLearn, F. H., and Hume, G. S., 1927, The stratigraphy and oil prospects of Alberta, Canada: Am. Assoc. Petroleum Geologists Bull., v. 11,.p. 237-260.

Mansfield, G. R., and Richards, R. W., 1912, The Bannock overthrust, a major fault in southeastern Idaho and northeastern Utah: Jour. Geology, v. 20, p. 681-709.

Mertie, J. B., Jr., Fischer, R. P., and Hobbs, S. W., 1951, Geology of the Canyon Ferry quadrangle, Mont.: U. S. Geol. Survey Bull. 972.

Pardee, J. T., 1925, Geology and ground-water resources of Townsend Valley, Mont.: U. S. Geol. Survey Water-Supply Paper 539.

- 1950,. Late Cenozoic block faulting in western Montana: Geol. Soc. America Bull., v. 61, p. 359-406.

Peale, A. C., 1893, The Paleozoic section in the vicinity of Three Forks, Mont.: U. S. Geol. Survey Bull. 110.

1896, Three Forks, Mont.: U. S. Geol. Survey Geol. Atlas, folio 24.

Reed, G. C., 1951, Mines and mineral deposits (except fuels), Broadwater County, Mont.: U. S. Bureau of Mines, Inf. Circ. 7592.

Richardson, G. B., 1913, The Paleozoic section in northern Utah: Am. Jour. Sci., 4 th ser., v. 36, p. $406-416$.

Rubey, W. W., 1929, Origin of the siliceous Mowry shale of the Black Hills region: U. S. Geol. Survey Prof. Paper 154-D.

Schmitt, G. T, 1953, Regional stratigraphic analysis of Middle and Upper Marine Jurassic in northern Rocky Mountains-Great Plains: Am. Assoc. Petroleum Geologists Bull., v. 37, p. 355-393.

Scott, H. W., 1935, Some carboniferous stratigraphy in Montana and northwestern Wyoming: Jour. Geology, v. 43, p. 1011-1032.

Sloss, L. L., and Laird, W. M., 1947, Devonian system in central and northwest Moṇtana: Am. Assoc. Petroleum Geologists Bull., v. 31, p. 1404-1430.

Swanson, R. W., McKelvey, V. E., and Sheldon, R. P., 1953, Progress report on investigations of western phosphate deposits: U. S. Geol. Survey Circ. 297.

Walcott, C. D., 1899, Pre-Cambrian fossiliferous formations: Geol. Soc. America Bull., v. 10, p. 199-244. 
GEOLOGY OF PART OF TOWNSEND VALLEY, MONTANA 553

Weed, W. H., 1896, Yellowstone Natl. Park: U. S. Geol. Survey Geol. Atlas folio 30 .

1900, Geology of the Little Belt Mountains, Mont.: U. S. Geol. Survey 20th Ann. Rept., pt. 3.

Wentworth, C. K., and Williams, Howel, 1932, The classification and terminology of the pyroclastic rocks: Natl. Research Council Bull. 89, Rept. Comm. Sedimentation 1930-32, p. 19-53.

Winchell, A. N., 1914, The mining districts of the Dillon quadrangle, Mont., and adjacent areas: U. S. Geol. Survey Bull. 574. 